\title{
FARELO DE SOJA EM SUBSTITUIÇÃO À URÉIA EM DIETAS PARA BOVINOS DE CORTE EM CRESCIMENTO E TERMINAÇÃO
}

\author{
JULIANO JOSÉ DE RESENDE FERNANDES
}

Tese apresentada à Escola Superior de Agricultura "Luiz de Queiroz", Universidade de São Paulo, para obtenção do título de Doutor em Agronomia, Área de Concentração: Ciência Animal e Pastagens.

\author{
P I R A C I C A B A \\ Estado de São Paulo - Brasil \\ Janeiro - 2004
}




\title{
FARELO DE SOJA EM SUBSTITUIÇÃO À URÉIA EM DIETAS PARA BOVINOS DE CORTE EM CRESCIMENTO E TERMINAÇÃO
}

\author{
JULIANO JOSÉ DE RESENDE FERNANDES
}

Médico Veterinário

Orientador: Prof. Dr. ALEXANDRE VAZ PIRES

Tese apresentada à Escola Superior de Agricultura "Luiz de Queiroz", Universidade de São Paulo, para obtenção do título de

Doutor em Agronomia, Área de Concentração: Ciência Animal e Pastagens.

P I R A C I C A B A

Estado de São Paulo - Brasil

Janeiro - 2004 


\title{
Dados Internacionais de Catalogação na Publicação (CIP) DIVSÃO DE BIBLIOTECA E DOCUMENTAÇÃO - ESALQ/USP
}

\author{
Fernandes, Juliano José de Resende \\ Farelo de soja em substituição à uréia em dietas para bovinos de corte \\ em crescimento e terminação / Juliano José de Resende Fernandes. - - \\ Piracicaba, 2004. \\ $74 \mathrm{p}$. \\ Tese (doutorado) - Escola Superior de Agricultura Luiz de Queiroz, 2004. \\ Bibliografia. \\ 1. Bovino de corte 2. Desempenho animal 3. Dieta animal 4. Farelo de \\ soja 5. Uréia I. Título
}

CDD 636.213

“Permitida a cópia total ou parcial deste documento, desde que citada a fonte - O autor” 


\section{DEDICO}

\section{A DEUS}

AOS MEUS QUERIDOS E AMADOS PAIS JALME E ZILDA,

AOS MEUS QUERIDOS IRMÃOS E SUAS

DIGNÍSSIMAS MARCO ALEXANDRE E CLAUDIA E JALME JR E MÁRCIA,

AO MEU AMIGÃO JOSÉ RENATO,

A MINHA LINDA SOBRINHA ANA VITÓRIA,

AO MEU QUERIDO AFILHADO MARCO

ALEXANDRE FILHO.

\section{OFEREÇO}




\section{AGRADECIMENTOS}

A Deus e ao meu espírito protetor por estar sempre ao meu lado.

À Escola Superior de Agricultura "Luiz de Queiroz" (ESALQ/USP), por intermédio do Departamento do Departamento Zootecnia, pela oportunidade e apoio de realização deste curso.

À Universidade Federal de Goiás que me proporcionou condições para o término deste trabalho.

À Coordenação de Aperfeiçoamento de Pessoas de Nível Superior (CAPES), pela concessão de bolsa de estudo.

Ao Prof. Dr. Alexandre Vaz Pires, pela orientação, pelos valiosos ensinamentos, pela amizade, pela confiança e pelo exemplo de vida e profissional.

À Prof ${ }^{\mathrm{a}}$. Dr ${ }^{\mathrm{a}}$. Ivanete Susin, pelos ensinamentos, pela amizade.

Ao Prof. Dr. Flávio Augusto Portela Santos, pelas sugestões na execução deste trabalho, pela atenção.

Aos demais Professores do Departamento de Produção Animal, pelos ensinamentos e pela amizade.

Aos professores do curso de Medicina Veterinária e Agronomia da UFG/CAJ, pela colaboração e amizade.

Aos meus Pais Jalme e Zilda, irmãos Marco Alexandre e Jalme Jr e cunhadas Cláudia e Márcia, pelo amor, carinho, apoio e incentivo.

Aos meus tios João Toledo e Zulma, que foram grandes amigos e me ajudaram na minha formação. 
Aos meus primos João Humberto e Ludmilla, que sempre estiveram junto comigo quando precisei.

Aos meus amigos Sr. José M. Filho e Dona Maria Felisbina (Dona Fia), pela amizade, carinho e incentivo.

Aos colegas de curso Márcia Helena Machado da Rocha Fernandes, Paulo Garcez de Oliveira e Janice Morais, pela amizade e pela agradável convivência.

Ao grande amigo e colega Reinaldo Jr., pela agradável convivência e pela amizade que cultivamos.

Aos estagiários Ricardo (Bronha) e Rafael (K-neco), pela amizade, e valiosa colaboração, sempre com muita responsabilidade, na realização deste trabalho.

A colaboração essencial dos estagiários: Brioko, (TXA) ${ }^{3}$, Brou, lena, Uruka, Melaku, Cascaku, Xixa e Isquerda.

A todos os estagiários do Clube de Praticas Zootécnicas que estiveram sempre juntos e contribuíram para a realização deste trabalho.

Aos funcionários do Departamento de Zootecnia Lauriano, Danilo e Benedito, pelas suas colaborações sempre que precisei e, sobretudo pela amizade.

A grandiosa República Zona Rural, que me acolheu (e acolhe) quando preciso.

Aos demais funcionários e colegas do curso de pós-graduação pela amizade e agradável convivência.

A todos que, diretamente ou indiretamente, contribuíram para a realização deste projeto. 


\section{SUMÁRIO}

Página

RESUMO viii

SUMMARY

1

INTRODUÇÃO

REVISÃO DE LITERATURA

01

2.3 Sistemas Protéicos (NRC, 1996 X CNCPS, Fox et al. 2000).................. 12

2.4 Fontes protéicas........................................................................ 20

3 FARELO DE SOJA EM SUBSTITUIÇÃO À URÉIA EM DIETAS PARA BOVINOS DE CORTE EM CRESCIMENTO .................................... 27

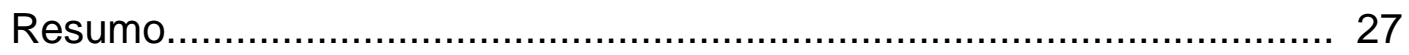

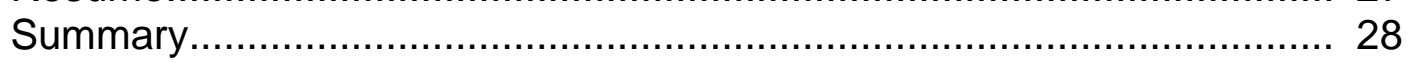

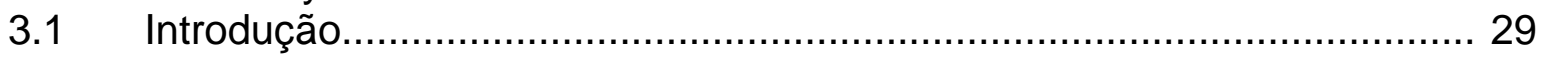

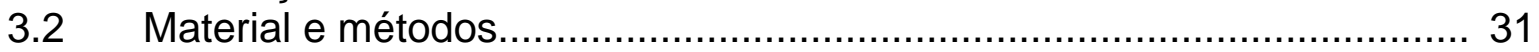

3.2.1 Animais e instalações experimentais.................................................. 31

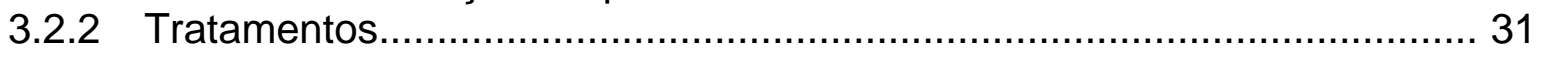

3.2.3 Período experimental................................................................... 34

3.2.4 Colheita dos dados de consumo de matéria seca................................. 34

3.2.5 Analise bromatológica das dietas e sobras........................................ 35

3.2.6 Pesagem dos animais................................................................ 35

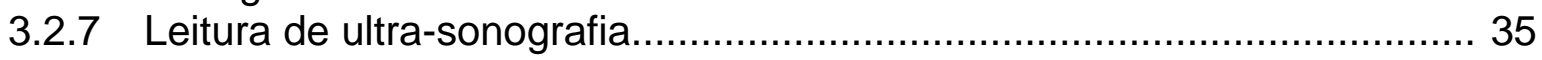

3.2.8 Delineamento experimental e análise estatística................................... 36

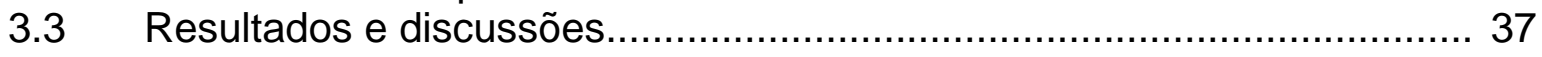

3.4 Conclusões.......................................................................... 42

4 FARELO DE SOJA EM SUBSTITUIÇÃO À URÉIA EM DIETAS PARA BOVINOS DE CORTE EM TERMINAÇÃO......................................... 43

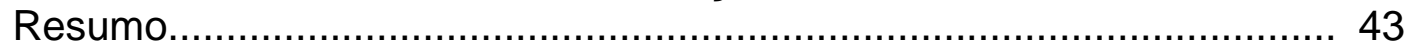

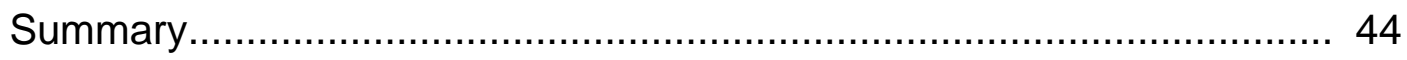

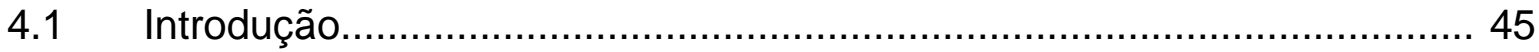

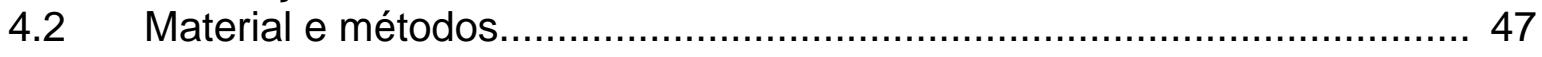

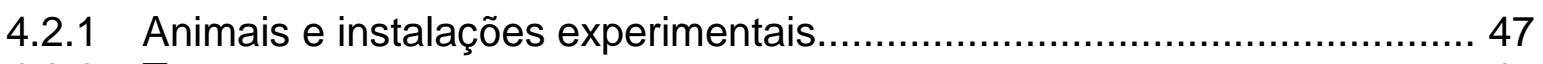

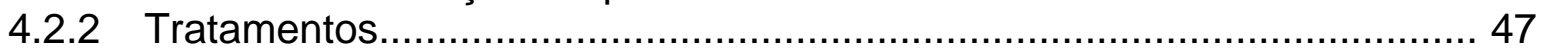

4.2.3 Período experimental.................................................................... 50

4.2.4 Colheita dos dados de consumo de matéria seca................................. 50

4.2.5 Analise bromatológica das dietas e sobras......................................... 50 
4.2.6 Pesagem dos animais......................................................... 51

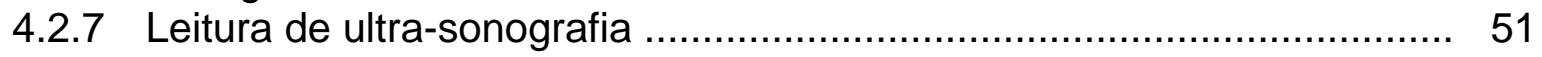

4.2.8 Delineamento experimental e análise estatística............................. 52

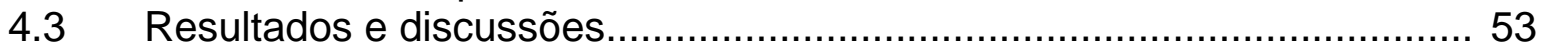

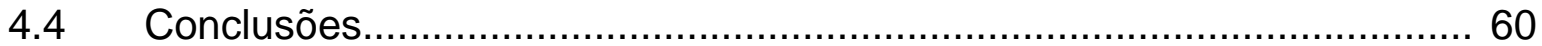

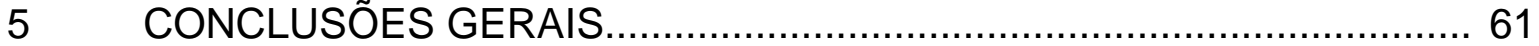

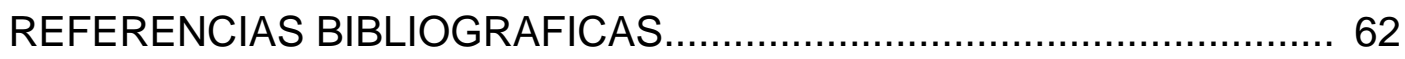




\title{
FARELO DE SOJA EM SUBSTITUIÇÃO À URÉIA EM DIETAS PARA BOVINOS DE CORTE EM CRESCIMENTO E TERMINAÇÃO
}

\author{
Autor: JULIANO JOSÉ DE RESENDE FERNANDES \\ Orientador: Prof. Dr. ALEXANDRE VAZ PIRES
}

\section{RESUMO}

O objetivo do presente trabalho foi avaliar o aumento no teor de proteína metabolizável da dieta, através da inclusão de farelo de soja em substituição à uréia no desempenho de bovinos machos não castrados em crescimento e terminação. Foram realizados dois experimentos de desempenho em confinamento. Experimento I: Foram utilizados 36 machos, não castrados, (24 Nelore e 12 Canchim), com peso médio inicial de $230 \mathrm{~kg}$ e média de 15 meses de idade. O delineamento experimental adotado foi o de blocos ao acaso, em que os animais foram agrupados por raça, peso e idade. O experimento foi conduzido no confinamento do Centro de Produção Intensiva de Bovinos de Corte do Departamento de Zootecnia da ESALQ-USP, onde os animais foram alojados em baias $(3 \times 11 \mathrm{~m})$ cobertas, com piso, cocho e bebedouro de concretos, sendo distribuídos dois animais por baia, num total de 18 baias. O período experimental foi realizado durante o período de agosto a dezembro de 2001 e teve duração de 84 dias, divididos em 4 subperíodos de 21 dias. As dietas foram balanceadas utilizando o modelo do NRC (1996), Nível 
I. O tratamento U continha 2,0\% de uréia e 4,1 de farelo de soja na MS da dieta e apresentou excesso de 159,4 g/dia de proteína degradável no rúmen (PDR). O tratamento FSU continha $1,0 \%$ de uréia e 11,5 de farelo de soja na MS da dieta e apresentou excesso de 79,1 g/dia de PDR. O tratamento FS continha $18,8 \%$ de farelo de soja como única fonte de proteína e, praticamente, atendeu com exatidão a PDR (excesso de 1g/dia). Os tratamentos continham energia metabolizável (EM) disponível para os seguintes ganhos: 1,31, 1,31 e 1,33 $\mathrm{kg} / \mathrm{d}$ para os tratamentos $\mathrm{U}, \mathrm{FSU}$ e FS, respectivamente, e proteína metabolizável disponível para ganhos de 1,03; 1,19 e 1,42 para os tratamentos $\mathrm{U}, \mathrm{FSU}$ e FS, respectivamente. Os ganhos de pesos observados entre os tratamentos foram: 1,$14 ; 1,26$ e 1,28 para os tratamentos $U$, FSU e FS, respectivamente. Os tratamentos FSU e FS não diferiram entre si, mas foram diferentes $(p<0,05)$ do tratamento $U$. Experimento II: Foram utilizados quarenta machos, (24 Nelore e 16 Canchim), com peso médio inicial de $400 \mathrm{~kg}$ e média de 20 meses de idade. $O$ delineamento experimental utilizado foi o de blocos ao acaso, em que os animais foram agrupados por raça, peso e idade. O experimento foi conduzido no confinamento do Centro de Produção Intensiva de Bovinos de Corte do Departamento de Zootecnia da ESALQ-USP. Os animais foram alojados em baias $(3 \times 11 \mathrm{~m})$ cobertas, com piso, cocho e bebedouro de concreto, sendo distribuídos dois animais por baia, num total de 20 baias. O período experimental teve a duração de 84 dias divididos em 4 subperíodos de 21 dias. As dietas foram formuladas utilizando o NRC (1996), Nível I, de modo a se obter um balanço de proteína degradável no rúmen superior a $80 \mathrm{~g} / \mathrm{dia}$ e energia metabolizável suficiente para ganho de peso diário de $1,40 \mathrm{~kg} / \mathrm{d}$, em todos os tratamentos. O tratamento $U$ continha $2,0 \%$ de uréia na matéria seca (MS), como a principal fonte de nitrogênio da dieta e proteína metabolizável, para ganho de peso diário (GPD) de $1,75 \mathrm{~kg} / \mathrm{animal}$. O tratamento FS continha $7,03 \%$ de farelo de soja e 1,01\% de uréia na MS da dieta, proteína metabolizável disponível para GPD de 2,09kg/animal. O consumo de MS (CMS) não foi afetado pelos tratamentos $(P>0,05)$, com 
valores de $12,1 \mathrm{Kg}$ de MS/cab. dia para o tratamento $U$ e $12,5 \mathrm{Kg}$ de MS/cab.dia para o tratamento FS. O GPD foi maior $(P<0,05)$ para os animais que receberam o tratamento com maior quantidade de proteína metabolizável $(\mathrm{FS} ; \mathrm{GPD}=1,46 \mathrm{~kg} / \mathrm{d})$ em relação aos animais que receberam o tratamento com menor quantidade de proteína metabolizável (U; GPD = 1,29kg/d). 


\title{
SOYBEAN MEAL AS A REPLACEMENT FOR UREA ON GROWING AND FINISHING BEEF STEERS DIETS
}

\author{
Author: JULIANO JOSÉ DE RESENDE FERNANDES \\ Adviser: Prof. Dr. ALEXANDRE VAZ PIRES
}

\section{SUMMARY}

Two trials were conducted to evaluate increasing diet metabolizable protein levels by soybean meal inclusion, replacing urea, on growing and finishing steers performance. Experiment I: Thirty-six steers, not castrated, (24 Nelore and 12 Canchim), with initial mean weight and age of 230 $\mathrm{kg}$ and 15 months, respectively, were assigned to completely randomized block design, according to genetic group, weight and age. Experiment was conducted at the Departamento de Zootecnia at ESALQ/USP, in the Intensive Beef Steers Center Feedlot. Animal were paired on covered pens $(3 \times 11 \mathrm{~m})$ with concrete floor, feed bulk and waterer, with a total of 18 pens. Experimental period was 84 days (August to December 2001), divided on 4 sub-periods of 21 days. Diets were formulated according to NRC (1996), Level I. Urea treatment (U) contained 2.0\% urea and $4.1 \%$ soybean meal (DM basis) and presented an excess of $159.4 \mathrm{~g} / \mathrm{d}$ of rumen degradable protein (RDP). Soybean meal and Urea treatment (FSU) contained of $1.0 \%$ urea and $11.5 \%$ soybean meal in diet DM and presented an excess of $79.1 \mathrm{~g} / \mathrm{d}$ of RDP. Soybean treatment FS contained of $18,8 \%$ soybean meal in diet DM as a single protein source and 
supplying almost the exact requirement of RDP (1.0 g/d excess). Treatments had metabolizable energy (ME) and metabolizable protein, respectively, available for average daily gain (ADG) of 1.31 and 1.03, 1.31 and 1.19, 1.33 and $1.42 \mathrm{~kg} / \mathrm{d}$ for treatments $\mathrm{U}, \mathrm{FSU}$ and FS, respectively. Simulations were done by the NRC (1996) program, Level I and II, adjusting the observed dry matter intake (DMI). Observed ADG were 1.14, 1.26 and $1.28 \mathrm{~kg}$ for treatments $\mathrm{U}, \mathrm{FSU}$ and FS, respectively. Treatments FSU and FS were not different but were different $(P<0.05)$ compared to Treatment $U$. Experiment II: Forty steers, not castrated, (24 Nelore and 16 Canchim), with initial mean weight and age of $400 \mathrm{~kg}$ and 20 months, respectively, were assigned to completely randomized block design, according to genetic group, weight and age. Experiment was conducted at the Departamento de Zootecnia at ESALQ/USP, in the Intensive Beef Steers Center feedlot. Animal were paired on covered pens $(3 \times 11 \mathrm{~m})$ with concrete floor, feed bulk and waterer, with a total of 20 pens. Experimental period was 84 days, divided on 4 sub-periods of 21 days. Diets were formulated according to NRC (1996), Level I , to have a rumen degradable protein (PDR) balance higher than $80 \mathrm{~g} / \mathrm{d}$ and metabolizable energy to assure a average daily gain (ADG) of $1.40 \mathrm{~kg}$ on all treatments. Treatment $U$ contained of $2.11 \%$ urea on diet DM as the main source of protein and metabolizable protein available for an ADG of $1.75 \mathrm{~kg} /$ animal. Treatment FS contained of $7.03 \%$ soybean meal and 1.01\% urea in diet DM and metabolizable protein available for an ADG of 2.09 $\mathrm{kg} / \mathrm{animal}$. Dry matter intake $(\mathrm{DMI})$ was not affected by treatments $(P<0.05)$, with values of $12.1 \mathrm{~kg} \mathrm{DM} / \mathrm{d}$ and $12.5 \mathrm{~kg} \mathrm{DM} / \mathrm{d}$ for Treatment $U$ and $\mathrm{FS}$, respectively. ADG was higher $(P<0.05)$ for animals receiving the higher metabolizable protein diet (FS: $1.46 \mathrm{~kg} / \mathrm{d}$ ) as compared to the lower metabolizable protein diet (U: $1.29 \mathrm{~kg} / \mathrm{d})$. 


\section{INTRODUÇÃO}

Com a tecnificação e desenvolvimento da produção pecuária, juntamente com o desenvolvimento e expansão da produção de grãos, a pratica de confinamento tem se expandido no Brasil, trazendo benefícios como a melhoria no ganho de peso em épocas de escassez de alimento, sobretudo de escassez forrageira, melhor aproveitamento da terra, além de benefícios na melhoria da qualidade da carcaça e da carne, tentando assim um aumento da lucratividade do produtor.

No Brasil, o confinamento de bovinos de corte é uma das técnicas utilizadas dentro da cadeia de produção da carne bovina, que, por sua vez, desempenha importante papel no processo de desenvolvimento sócioeconômico, como supridora de alimento nobre para a população, matéria prima para a indústria e na geração de divisas por meio das exportações. Entretanto, ainda há um grande desafio para pesquisadores, técnicos e produtores, no que diz respeito aos baixos índices zootécnicos e um mercado inconstante.

$\mathrm{Na}$ formulação de uma dieta completa para bovinos, deve-se considerar o fornecimento de níveis adequados de matéria seca (MS), energia, proteína bruta (PB), fibra em detergente neutro (FDN), fibra em detergente ácido (FDA), extrato etéreo (EE), além de minerais e vitaminas (Silva, 2002).

Quando se trata de nutrição animal, sabe-se que a quantidade e equilíbrio entre os nutrientes em uma dieta são fatores de grande relevância e que os seus ajustes são essenciais para o metabolismo e um bom desempenho produtivo. 
As exigências protéicas dos ruminantes são atendidas pelos aminoácidos absorvidos no intestino delgado, sendo estes provenientes da proteína microbiana e da proteína dietética não degradada no rúmen (Valadares Filho, 1995). Essas juntamente com os aminoácidos endógenos formam a proteína metabolizável.

$\mathrm{Na}$ nutrição de ruminantes, o balanceamento de dietas tem uma grande ressalva, pois o rúmen é um órgão com uma grande capacidade de transformação, podendo degradar alimentos de baixa qualidade e transformá-lo em nutrientes de alto valor nutricional.

No que diz respeito ao suprimento de proteína aos ruminantes, os primeiros estudos vieram para embasar o que diz respeito ao teor de proteína de uma dieta para uma determinada categoria. Um próximo passo foi mensurar a degradabilidade ruminal das porções protéicas da dieta, passando pela fase em que se tratava apenas da porção degradável e não degradável no rúmen, indo até as porções: altamente degrádavel, parcialmente degradável e não degradável no rúmen. Já estudos mais recentes têm tentado mensurar as exigências nutricionais dos ruminantes no que se diz respeito a balanceamento de aminoácidos.

O estudo da digestão de $\mathrm{N}$ nos ruminantes e seu metabolismo não requer apenas conhecimento da composição da proteína dos tecidos e a necessidade de aminoácidos, mas também envolve o metabolismo do $\mathrm{N}$ e o requerimento da microbiota do trato gastrintestinal, principalmente a ruminal. Vários trabalhos foram realizados nas ultimas duas décadas para determinação do valor ideal de PB para animais de corte em crescimento e terminação. $\mathrm{Na}$ revisão realizada pela Nutrient Requirements of Beef Cattle $(N R C, 1996)$ utiliza proteína metabolizável para determinação do requerimento de proteína.

Com avanço da nutrição protéica, o modelo do NRC (1996) pode contribuir com a produção de proteína microbiana, pois sabe-se que, para que ocorra a síntese de proteína microbiana com máxima eficiência, é necessário 
que se tenha PDR adequadas (amônia, peptídeos e aminoácidos; Russell et al., 1992).

Em relação às exigências líquidas de proteína para ganho, à medida que aumentam o peso vivo e as taxas de ganho de peso do animal, ocorre diminuição dos mesmos, fato descrito pelo NRC $(1984,1996)$.

As bactérias fermentadoras de fibras utilizam amônia como fonte preferencial de nitrogênio, sendo esasas altamente prejudicadas quando há deficiência de nitrogênio no rúmen, levando a um menor desaparecimento da fibra, diminuindo, com isso, a taxa de passagem e, conseqüentemente, o consumo de matéria seca (Russell et al., 1983, 1992 e Tedeschi 2000). A amônia pode ser fornecida via uréia, embora apresente uma alta solubilidade no rúmen, limitando a sua utilização.

Em regiões com uma alta produção de grãos ou até mesmo regiões com alta concentração de agroindústrias, onde há grande disponibilidade de subprodutos, a utilização de dietas com altos teores de concentrado é bem vantajosas. No Brasil, essa prática não é muito utilizada, onde temos a utilização de dietas para confinamento com altas proporções de alimento volumoso (mais que 18\% de fibra bruta). As regiões do Centro Oeste brasileiro, que se caracteriza por altas produções de grão, ainda não atinaram para o grande potencial existente com o uso de altos teores de grão na dieta.

Diante disso, os objetivos do presente trabalho foram comparar o efeito da substituição de uma fonte de proteína verdadeira (farelo de soja), por uréia (nitrogênio não protéico com alta degradação ruminal) no desempenho de bovinos de corte em crescimento (capítulo 3) e terminação (capítulo 4). 


\section{Revisão de Literatura}

\subsection{Considerações sobre o metabolismo protéico em ruminantes}

Em ruminantes, os alimentos são primeiramente fermentados no rúmen antes da digestão gástrica e intestinal, sendo que a qualidade e quantidade dos produtos dessa fermentação são dependentes das atividades microbianas no rúmen, onde o ecossistema microbiano ruminal é muito complexo, uma vez que há numerosas interrelações entre os vários tipos e espécies de microrganismos (Russel et. al., 1992).

Dessa forma, estabelecer as condições sob as quais a fermentação ruminal será otimizada exige um entendimento das exigências nutricionais da população microbiana. Os principais nutrientes exigidos pelos microorganismos são carboidratos e proteínas, entretanto, a determinação da melhor fonte ou quantidade desses nutrientes, para que haja um máximo crescimento microbiano ainda não esta bem estabelecida. A digestão da proteína resulta na produção de peptídeos, os quais serão hidrolisados em aminoácidos e alguns serão deaminados, produzindo amônia (Hoover \& Stokes, 1991).

Em muitas situações, a maior parte do $\mathrm{N}$ de aminoácidos que chega aos intestinos é de origem microbiana, e essa dependência da proteína microbiana significa que a eficiência do crescimento microbiano constitui um fator importante para o ruminante. Os microrganismos podem utilizar amônia, entretanto, em alguns casos, a taxa de produção ruminal pode exceder a taxa 
de utilização, levando a um aumento na excreção de $\mathrm{N}$ e a um custo energético proveniente da síntese de uréia (Russel et. al., 1992).

Em uma revisão apresentada por Hoover \& Stokes (1991), os autores sugerem que a máxima digestão da MS, eficiência microbiana e produção de proteína microbiana seriam alcançadas quando a dieta estivesse entre 10 a 13\% de proteína degradável no rúmen (PDR) e 56\% dos carboidratos totais como carboidratos não estruturais (CNE).

Entretanto, em dietas com grãos altamente processados, os quais contêm elevada proporção de CNE e provêem grandes quantidades de MO fermentescíveis, pode haver um aumento na exigência microbiana por PDR. Se a PDR estiver limitada, a produção total de energia proveniente da fermentação e, em conseqüência o desempenho animal, podem ser afetados (Galyean, 1996). Milton et al. (1997b) observaram que a adição de uréia em dietas de terminação com alta proporção de grãos proporcionou um aumento na digestão de amido no rúmen e no trato digestivo total.

Limitações em PDR para os microrganismos parece ser mais crítico com dietas com alta proporção de grãos altamente processados (por exemplo: floculado), dietas tipicamente americanas. O milho de alta umidade é uma exceção a esta generalização (Cooper et al., 2002). Cooper et al. (2002), utilizando animais em terminação com uma dieta com alta proporção de milho (82\% da MS) e uréia como a única fonte de $\mathrm{N}$ suplementar, verificaram que a exigência em PDR foi dependente do processamento do grão. Os autores observaram que a exigência em PDR para o milho laminado, de alta umidade para o floculado, foi de $6,3 \%, 10,2 \%$ e $8,3 \%$, respectivamente.

Assumindo que dietas altamente fermentescíveis estão com PDR limitada para os microrganismos, o sistema de PM do NRC (1996) estima as exigências de proteína mais precisamente do que o NRC (1984), o qual não considera diretamente as exigências microbianas, que geralmente não eram satisfeitas. 
A produção de proteína microbiana $(\mathrm{gN})$ é calculada pelo produto da quantidade de substrato fermentado no rúmen ( $\mathrm{kg}$ de $\mathrm{CHO}$ ) multiplicada pela eficiência microbiana ( $\mathrm{gN} / \mathrm{kg} \mathrm{CHO}$ fermentado). Se se assumir que a relação típica entre $\mathrm{N}$ microbiano sintetizado e $\mathrm{MO}$ verdadeiramente fermentada no rúmen é de $25 \mathrm{~g} / \mathrm{kg}$ em dietas de terminação com grãos altamente processados (Zinn, 1995 e Devant et al., 2001), e que o $\mathrm{N}$ deve ser provido totalmente na forma de PDR, com uma digestibilidade verdadeira da MO de 60\%, a PB da dieta, na forma de PDR deveria ser de aproximadamente 9,4\% (Zinn, 1995).

Os ácidos graxos voláteis (AGV) provenientes da fermentação ruminal são a principal fonte de energia para o animal. Acetato e butirato são usados eficientemente por animais em crescimento, mas não fazem uma contribuição líquida para o suprimento de glucose, sendo o propionato usado para a gluconeogênese. Se a taxa de fermentação é rápida, pode haver um acúmulo de ácido lático. O lactato pode ser convertido em glucose sanguínea, mas é um ácido muito mais forte que os AGV, e seu acúmulo pode levar a uma acidose ruminal, diminuindo a digestão de fibra. Estudos in vitro indicam que a eficiência da síntese de proteína microbiana pode cair signitivamente em valores de $\mathrm{pH}$ abaixo de 6,0. A metanogênese pode ser uma alternativa para reduzir o equivalente hidrogeniônico, entretanto a produção de metano representa uma importante perda de energia (Russel et. al., 1992).

İtavo et al. (2002), ao testar em dietas isonitrogenadas (15\% PB), contendo vários teores de concentrado (20, 40, 60 e 80\% na MS) e adicionando bicarbonato de sódio nas dietas com 60 e $80 \%$ de concentrado, verificaram que a composição das bactérias ruminais e a eficiência de síntese de proteína microbiana não foram influenciadas pelo teor de concentrado das dietas, observando um valor médio para eficiência de 392,4g de MS microbiana/kg de carboidratos totais degradados no rúmen (CHODR).

O rúmen é o principal fornecedor de proteína de alta qualidade (PM) e, sendo assim, deve-se maximizar a fermentação ruminal e produção de proteína microbiana. Para isso, deve-se: 1) fornecer um volumoso de alta 
qualidade para maximizar o CMS da dieta; 2) otimizar a degradabilidade ruminal do amido presente nos cereais, aumentando o suprimento de energia para os microrganismos do rúmen; 3) suprir os microrganismos ruminais com quantidades adequadas de PDR, a fim de fornecer amônia, aminoácidos e peptídeos para a síntese de proteína microbiana; 4) quando da inclusão na dieta de fontes ricas em PNDR para complementar a proteína microbiana, devem-se usar fontes ricas em AAE e bem balanceadas (Santos, 1997).

\subsection{Exigências Nutricionais para Gado de Corte segundo o NRC (1996)}

O modelo do NRC (1996) utiliza um sistema de entrada de dados, em que descreve o ambiente da propriedade que ira utilizar a dieta e também uma descrição detalhada do animal. Esses dados são utilizados para calcular exigências para mantença, que varia com a raça, nível nutricional, exigências para ganho, dependendo do peso ao abate e composição da carcaça. Também para vacas, o modelo varia, dependendo do nível de produção de leite e mês de lactação.

O programa do NRC (1996) nível I é um sistema mais conservador que considera o rúmen estático, não tornando tão relevante a cinética ruminal, já o nível II é mais dinâmico, pois utiliza o sistema de Cornell como base. Tanto o nível I quanto o II do NRC (1996) faz uma estimativa de requerimento de energia e proteína disponível depois da digestão. A escolha de um ou outro modelo depende da perfeição de entrada das composições dos alimentos e do grau de conhecimento do uso dos mesmos. O modelo I é mais tradicional e utiliza, para encontrar os requerimentos de nutrientes, o valor de energia da dieta, proteína bruta e proteína degradável no rúmen. Entretanto, o modelo II utiliza a energia líquida e valor de proteína para cada situação, dependendo do conteúdo de carboidratos e as frações de proteína.

O modelo nível I do NRC (1996) utiliza o sistema de energia líquida proposto por Lofgreen e Garrett (1968), e é utilizado para descrever a 
energia dos alimentos. Entretanto, os dados de NDT são utilizados para predizer a produção de proteína microbiana no rúmen. O NRC (1996) prevê equações para predição de energia líquida da energia digestiva ou NDT, que é 0,82 da energia digestível.

Para o nível I do modelo do NRC (1996), a degradação da proteína é estimada através da degradação da proteína no rúmen, sendo essa a proteína degradável, e a diferença dessa porção da proteína bruta consumida tem-se a porção não degradável. No nível I a proteína degradável no rúmen e a não degradável são estáticas (dependendo do nível do consumo de matéria seca), para os alimentos e baseadas nos valores de publicações de várias fontes e de vários métodos.

O NRC (1996) (Figura 1) calcula a exigência de proteína degradável no rúmen (PDR) em função da produção estimada de proteína microbiana, sendo a produção de proteína microbiana 13\% dos nutrientes digestiveis totais (NDT), $1 \mathrm{~kg}$ de PB microbiana (PBM) $=1 \mathrm{~kg}$ de PDR. Por outro lado, Zinn \& Shen (1998) comentaram que este método de calcular a exigência de PDR é conservador, porque o $\mathrm{N}$ microbiano só reduz quando a PDR é menor que 70 a $80 \%$ do $\mathrm{N}$ bacteriano para o intestino, recomendando um mínimo de $100 \mathrm{~g}$ de proteína degradável no rúmen por kg de matéria orgânica (MO) digestivel (0,7 a 0,8 $\mathrm{Kg}$ de PDR $=1 \mathrm{~kg}$ PBM).

O valor de $13 \%$ do NDT para estimar a produção de proteína microbiana é um valor médio para a maioria das dietas, entretanto, estava implícito que essa recomendação não é apropriada para animais consumindo forragem de baixa qualidade ou dieta com concentrados extremamente altos (NRC, 1996 e Martnis et al. 2000). Foi considerado, no NRC (1996) nível I, que a reciclagem de $\mathrm{N}$ é igual às perdas de $\mathrm{N}$ no rúmen, quando as exigências de PDR (13\% do NDT) são satisfeitas, ressaltando que isso não é valido para dietas com teor de concentrado extremamente alto ou com forragens de baixa qualidade. 
No nível II do modelo do NRC (1996), o total de carboidratos é estimado pela subtração da soma da gordura, cinza e proteína bruta da matéria seca do alimento. Similarmente carboidratos não fibrosos (CÑF) são estimados pela subtração do FDN do carboidrato total do alimento. Os CÑF são fracionados em amido e pela diferença do total, são estimados os açúcares, que incluem ácidos orgânicos. Para determinar a fibra disponível aos microorganismos ruminais, o Nitrogênio insolúvel em detergente neutro deve ser subtraído do FDN, pois essa fração já está contabilizada na fração de proteína bruta. Esse processo está demonstrado na Figura 2. 


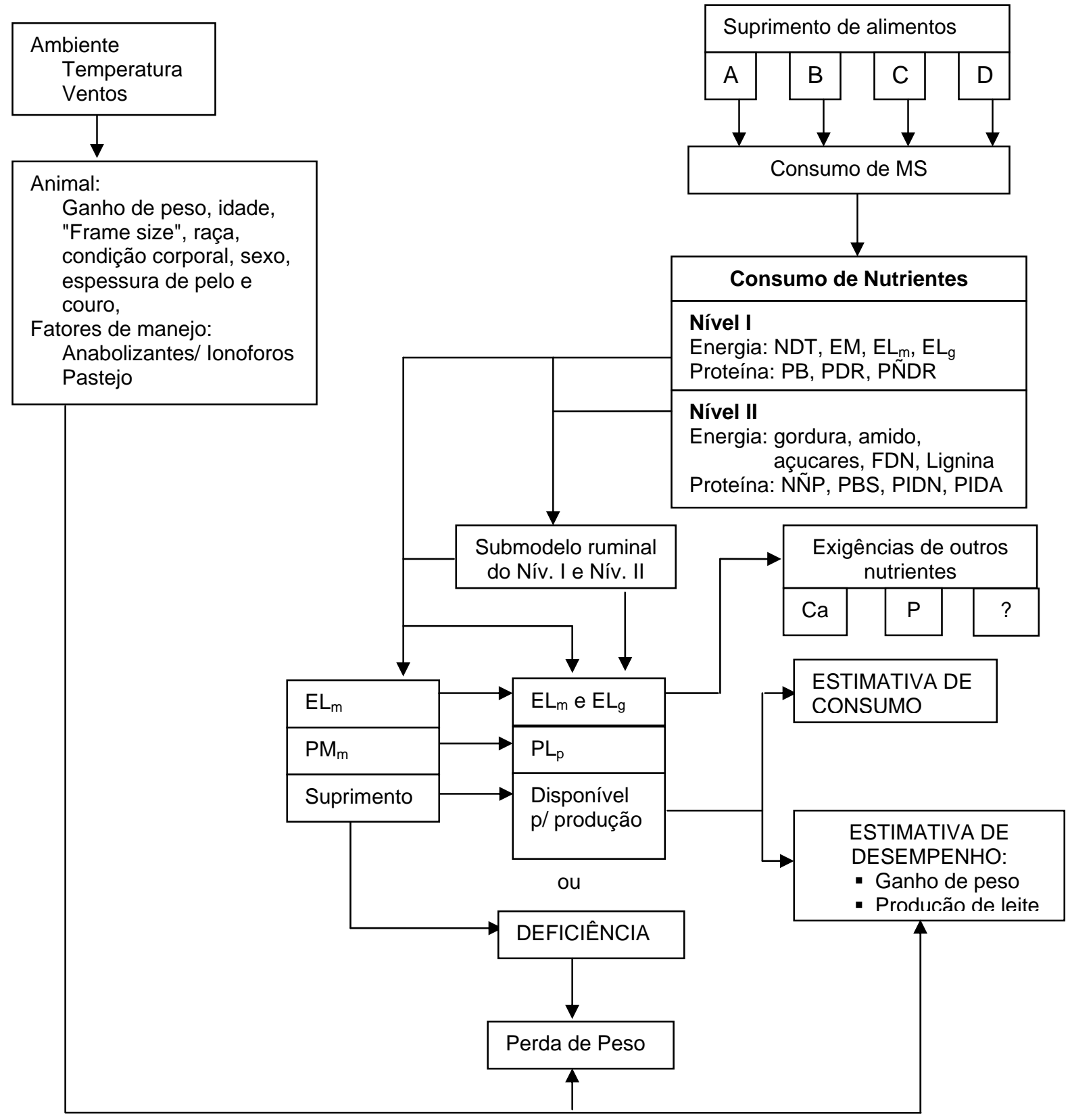

$\mathrm{NDT}=$ nutrientes digestíveis totais; $\mathrm{EM}=$ energia metabolizável; $\mathrm{EL}_{\mathrm{m}}=$ =energia líquida para mantença; $\mathrm{EL}_{\mathrm{g}}=$ energia líquida para ganho; $\mathrm{PB}$ = proteína bruta; $\mathrm{PÑNDR}$ = proteína não degradavel no rúmen; $\mathrm{PDR}=$ proteína degradável no rúmen; $F D N=$ fibra insolúvel em detergente neutro, NÑP = nitrogênio não protéico; PBS = proteína bruta solúvel; PIDN = proteína insolúvel em detergente neutro, PIDA = proteína insolúvel em detergente ácido; $\mathrm{PM}_{\mathrm{m}}=$ proteína metabolizável para mantença; $\mathrm{PL}_{p}=$ proteína líquida para produção.

Figura 1- Modelo do NRC (1996) para exigência de gado de corte 


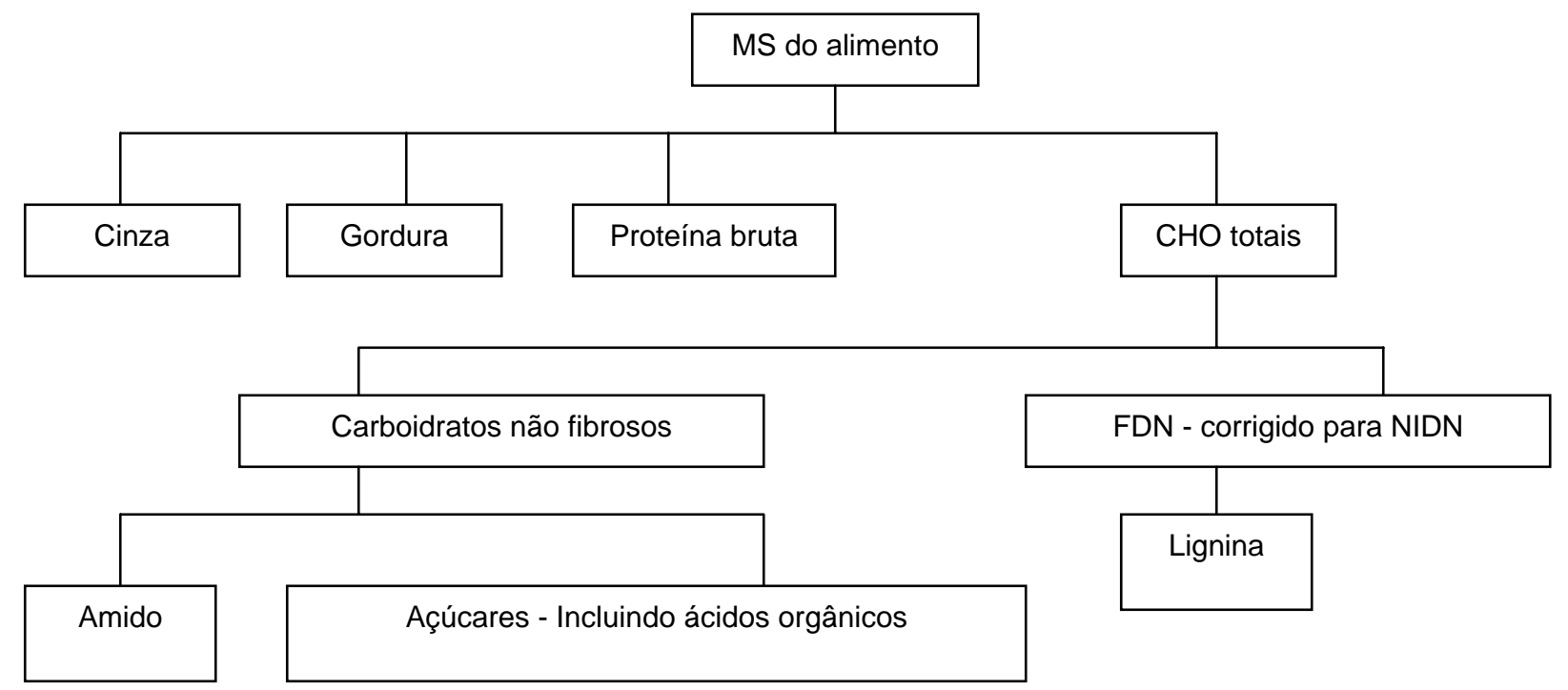

MS = matéria seca; $\mathrm{CHO}=$ carboidratos; FDN = fibra insolúvel em detergente neutro; NIDN = nitrogênio insolúvel em detergente neutro.

Figura 2 - Fração da matéria seca para determinação dos componentes dos carboidratos, segundo o modelo do NRC (1996), nível II

A proteína no nível II do modelo do NRC (1996) é fracionada em proteína bruta, proteína solúvel, nitrogênio insolúvel em detergente neutro e nitrogênio insolúvel em detergente ácido. A proteína solúvel é fracionada posteriormente em nitrogênio não protéico (NÑP) e proteína verdadeira solúvel. (Figura 3).

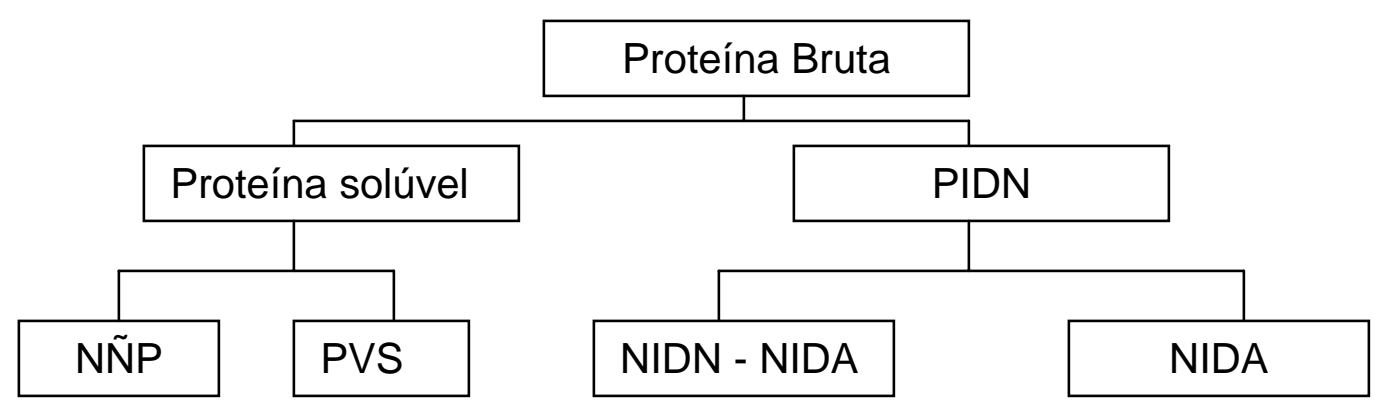

PIDN = proteína insolúvel em detergente neutro; NÑP = nitrogênio não protéico; PVS = proteína verdadeira solúvel; NIDN = nitrogênio insolúvel em detergente neutro; NIDA = nitrogênio insolúvel em detergente ácido.

Figura 3 - Componentes da proteína bruta, segundo o NRC (1996) 


\subsection{Sistemas Protéicos (NRC; 1996 x CNCPS; Fox et al. 2000)}

Tradicionalmente, as rações para ruminantes têm sido balanceadas de acordo com quantidades específicas de nutrientes. Entretanto, muitos trabalhos têm indicado que a taxa de degradação dos alimentos podem ter um efeito significante nos produtos finais da fermentação e no desempenho animal, como: 1- se a taxa de degradação de proteína excede a taxa de fermentação de carboidratos, grandes quantidades de $\mathrm{N}$ são perdidos na forma de amônia, 2- se a taxa de fermentação de carboidratos excede a taxa de degradação de proteína, a produção de proteína microbiana diminui, 3- se os alimentos são degradados lentamente, o enchimento ruminal diminui o consumo e 4- se a taxa de degradação é baixa, parte do alimento pode escapar da fermentação ruminal e passar diretamente para o intestino (Russel et. al., 1992).

Segundo Santos (1998), por muitos anos, a proteína bruta foi o principal parâmetro usado para a determinação das exigências protéicas na formulação de dietas para bovinos, devido, principalmente, à falta de informação e dados sobre a degradabilidade ruminal e o balanço de aminoácidos tanto das fontes protéicas como das exigências do animal. $\mathrm{O}$ fato do ruminante ter a habilidade única de sobreviver e produzir sem uma fonte de proteína dietética devido à síntese de proteína microbiana no rúmen, uma proteína de excelente qualidade, contribuiu para um retardamento na busca de métodos mais sofisticados para a determinação das exigências protéicas.

O sistema mais difundido na América do Norte é o sistema de "proteína absorvida" proposto pelo NRC (1984), o qual usa um método fatorial para estimar as exigências de proteína absorvida para todas as categorias.

O NRC (1984) calculava a exigência de proteína pelo método fatorial, expressando-a em termos de proteína bruta (PB), em que considerava quatro fatores: $\mathrm{N}$ metabólico fecal, proteína líquida depositada no ganho e as perdas de $\mathrm{N}$ endógeno na urina e por escamação. A exigência de proteína bruta 
da dieta era calculada e corrigida para digestibilidade verdadeira (90\%) e valor biológico da absorção de aminoácidos (66\%). Essas estimativas foram alteradas no NRC (1996), em que as exigências de proteína são expressas em termos de proteína absorvida, a qual se tornou sinônimo de proteína metabolizável (PM).

Proteína metabolizável é definida como a proteína verdadeira absorvida pelo intestino, compreendida pela proteína microbiana e a proteína ingerida não degradada no rúmen. Este sistema leva em consideração a degradação ruminal protéica, dividindo as exigências em termos de componente animal e componente microbiano, ou seja, em proteína não degradável no rúmen (PNDR) e proteína degradável no rúmen (PDR). Isso foi um avanço, pois é de fundamental importância a síntese de proteína microbiana e, para que esta ocorra, é necessário que se tenha proteína degradável no rúmen (PDR) em quantidade e qualidade.

As exigências de proteína do NRC (1996) geralmente são superiores às do NRC (1984) devido, principalmente, à exigência microbiana (PDR). O NRC (1996) ainda utiliza dois modelos para determinar as exigências protéicas: nível I e nível II. O modelo nível I usa os valores de PDR e PNDR dos alimentos contidos em uma biblioteca própria. Já o modelo nível II é mecanístico e utiliza as taxas de degradação de proteína de várias frações protéicas para estimar PDR e PNDR, além de incluir o suprimento e exigência para aminoácidos.

O valor de $13 \%$ do NDT para estimar a produção de proteína microbiana é um valor médio para a maioria das dietas, não sendo apropriada para animais consumindo forragem de baixa qualidade ou dieta com concentrados extremamente altos (NRC, 1996). Marthis et al. (2000), comparando diferentes teores de PDR em três forragens de baixa qualidade, bermudagrass (8,2\% PB e 71\% FDN), bromegrass (5,9\% PB e $65 \%$ FDN) e feno de sorgo forrageiro (4,3\% PB e 60\% FDN), observaram que a porcentagem de PDR, para maximizar o consumo de MO digestível foi 8,2\% 
para bermudagrass, 9,8\% para bromegrass e $12,8 \%$ para o sorgo forrageiro (maior nível testado). Os autores elucidaram que a reciclagem de $\mathrm{N}$ é um importante fator a ser considerado e que contribui para o "pool" de $\mathrm{N}$ degradado no rúmen. Considerando a reciclagem de $\mathrm{N}$, a quantidade de PDR consumida para alcançar o máximo consumo de forragem e digestibilidade deve ser aproximadamente 8 a 13\% do total de MO digestível.

A quantidade e a proporção do $\mathrm{N}$ reciclado em ruminantes respondem a uma variedade de fatores alimentares, incluindo teor de $\mathrm{N}$ (Bunting et al., 1987; Ferrell et al., 2001), degradabilidade do $\mathrm{N}$ na dieta (Ferrell et al., 2001), proporção forragem:concentrado (Huntington et al., 1996) e consumo de carboidratos rapidamente fermentáveis (Alio et al., 2000; Theurer et al., 2002). A reciclagem de $\mathrm{N}$ para o "portal-drained víscera" (PDV) é de importância substancial para a economia de $\mathrm{N}$ em ruminantes, especialmente quando a dieta apresenta baixa concentração de N. Entretanto, essas quantidades variáveis e significativas de $\mathrm{N}$ reciclado podem causar problemas na estimativa das exigências protéicas para o animal (Ferell et al., 2001). O sistema de reciclagem de nitrogênio no rúmen se adapta facilmente à rapidez da liberação de amônia pelas fontes de nitrogênio não protéico, desde que as concentrações não atinjam níveis tóxicos (Owens \& Zinn, 1988).

As recomendações do NRC (1996) propõem equações empíricas para estimar o fluxo de proteína microbiana proveniente do rúmen e apresentam algumas limitações: 1) o crescimento microbiano é função do NDT e não dos carboidratos disponíveis no rúmen; 2) o crescimento microbiano é constante; 3) a relação fundamental entre produção microbiana e exigência energética dos microrganismos é ignorada; 4) a população microbiana não é dividida de acordo com a atividade metabólica e exigência nitrogenada; 5) a taxa de fermentação dos carboidratos não é integrada com a taxa de degradação da proteína e 6) a degradação dos alimentos é fixa.

Silva et al. (2002) avaliaram as exigências líquidas e dietéticas de energia, de proteína e de macroelementos minerais de bovinos de corte no 
Brasil, everificaram que as exigências de PB preconizadas pelo NRC (1996) apresentaram-se com valores um pouco superiores aos obtidos para animais zebuínos e Holandeses com peso vivo (PV) inferiores a $300 \mathrm{~kg}$, mas com valores inferiores aos obtidos para animais com PV superiores a $300 \mathrm{~kg}$. Para as estimativas das exigências de PDR, os autores utilizaram o protocolo do NRC (1996) e verificaram que, com o aumento do PV do animal, a porcentagem da exigência da PB suprida pela PDR elevou-se. Para animais zebuínos e Holandeses com PV acima de $450 \mathrm{~kg}$, a quantidade de PDR fornecida por uma dieta com $66 \%$ de NDT e assumindo um consumo de MS de 2,4\% PV, foi suficiente para suprir a exigência total de PB. Com o aumento do teor de energia da dieta (72\% de NDT), um animal com $400 \mathrm{~kg}$ já não necessita de grande quantidade de PNDR para suprir as exigências totais de PB.

O sistema de Cornell, "Cornell Net Carbohydrate and Protein System" (CNCPS), é um sistema dinâmico o qual tem um submodelo de fermentação que compara as taxas de fermentação de carboidratos com as de degradação de proteína e estima a quantidade de matéria orgânica digerida no rúmen, síntese de proteína microbiana, produção de amônia e fluxo de material não digerido para o intestino delgado (Russell et al., 1992, Sniffen et al., 1992 e Fox et al., 1992).

O CNCPS divide o ecossistema microbiano ruminal em dois grupos: os microrganismos que fermentam carboidratos estruturais (CE) e os que fermentam carboidratos não estruturais (CNE). Essa segregação reflete as diferenças na utilização do $\mathrm{N}$ e eficiência de crescimento, bem como uma divisão quase exclusiva da fonte de energia utilizada. As bactérias pertencentes ao primeiro grupo (CE) fermentam apenas carboidratos da parede celular e usam somente a amônia como fonte de $\mathrm{N}$. As bactérias pertencentes ao segundo grupo (CNE) fermentam apenas carboidratos não estruturais (amido, pectina, açúcares, etc.), usam como fonte de $\mathrm{N}$ peptídeos, aminoácidos e amônia e podem produzir amônia (Russel et. al., 1992). 
Neste sistema, a proteína do alimento é dividida em três frações: nitrogênio rapidamente solúvel no rúmen, proteína verdadeira e nitrogênio não disponível, as quais representam frações A, B e C, respectivamente. A proteína verdadeira é dividida em três subfrações (B1, B2 e B3) de acordo com a taxa de degradação ruminal inerente. A fração $A$ é rapidamente convertida em amônia no rúmen. A fração B1 é rapidamente degradada no rúmen. A fração B2 é parcialmente fermentada no rúmen, escapando uma parte para o intestino. A fração B3 é degradada lentamente no rúmen devido à sua associação com a parede celular. A fração $C$ contém proteína associada com lignina, complexos proteína-tanino e produtos da reação de Maillard que são altamente resistentes às enzimas microbianas e dos mamíferos (Sniffen et al., 1992).

Com o objetivo de viabilizar o uso do Cornell em condições brasileiras, Pereira et al. (1997) estudaram a composição bromatológica, as degradabilidades potencial e efetiva de subfrações dos carboidratos e da proteína e a taxa de passagem da fase sólida para silagem de milho, em dietas com proporção de volumoso: concentrado de 80:20 (D1) e 60:40 (D2), utilizando bovinos da raça Nelore. Por intermédio do CNCPS, as subdivisões da fração protéica foram estimadas, em que $A=40 \%, B 1=0,9 \%, B 2=37,3 \%, B 3=$ $8,7 \%$ e $C=12,6 \%$. Os valores observados de nitrogênio insolúvel em detergente neutro (NIDN) e nitrogênio insolúvel em detergente ácido (NIDA) foram 21,3 e $12,6 \%$, respectivamente. Esses valores foram superiores em mais de $30 \%$ à silagem correspondente no modelo (16\% NIDN e 9\% NIDA), indicando provável subestimativa por parte do modelo quanto à proteína disponível neste alimento. Os autores também verificaram que a degradabilidade da PB $(80,9 \%)$ e as taxas de degradação do NIDN (2,7\%/h para D1 e 1,8\%/h para D2) foram superiores às estimativas feitas pelo CNCPS, podendo ser devido características intrínsecas dos animais utilizados, associadas ou não a fatores proporcionados pela própria dieta.

Apesar do CNCPS usar taxas de fermentação de carboidratos para estimar crescimento microbiano no rúmen (Russel et al., 1992), a 
produção de proteína microbiana é ajustada para "acomodar" os gastos de energia de mantença, a disponibilidade de peptídeos e o $\mathrm{pH}$, não tendo uma previsão para uma limitação de $N$ (Tedeschi et al., 2000). A limitação de N ruminal pode diminuir o fluxo de proteína microbiana ( $\mathrm{g}$ bactéria/dia), a fermentação da fibra e o consumo de matéria seca (Van Soest, 1994). Em dieta com deficiência de nitrogênio, há casos em que a energia metabolizável (EM) é o primeiro nutriente limitante. A limitação de $\mathrm{N}$ também causa uma superestimação da EM disponível para ganho, pois reduz a digestibilidade dos carboidratos fibrosos (CF). Entretanto, a superestimação mais comum é a de PM disponível para ganho (Tedeschi et al., 2000). As bactérias fermentadoras de carboidratos não fibrosos (CNF), utilizam $66 \%$ do $\mathrm{N}$ provenientes de peptídeos ou aminoácidos e 34\% provenientes de amônia. Quando os peptídeos e aminoácidos não são disponíveis em quantidade, todo $\mathrm{N}$ é proveniente da amônia (Russell et al., 1992).

Tedeschi et al. (2000) propuseram, então, ajustes algorítimos na estrutura do CNCPS para melhorar as estimativas da produção microbiana e da digestão da parede celular, quando há deficiência de $\mathrm{N}$ ruminal, cujos processos estão sumarizados na Figura 3. 


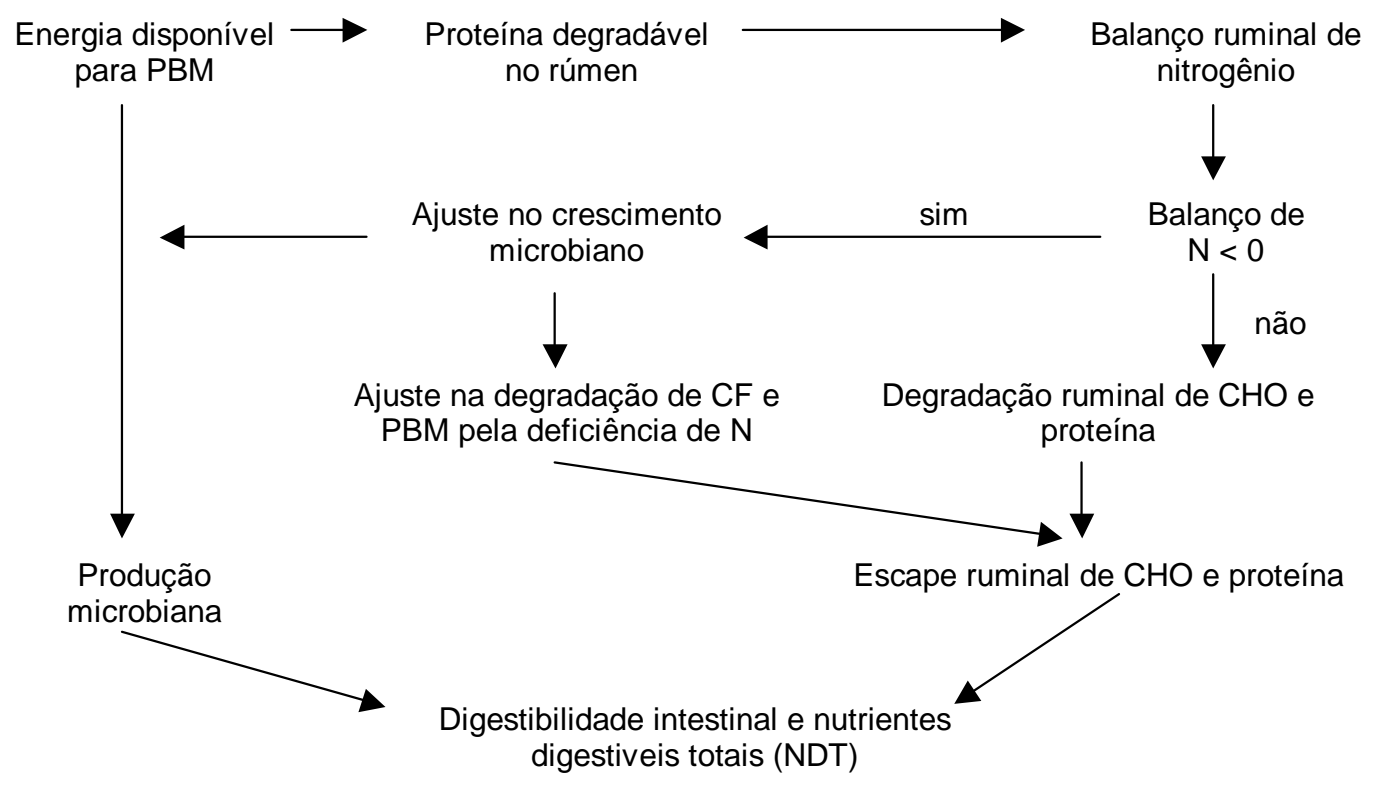

Figura 3. Processo de ajuste da produção de proteína microbiana e da degradação ruminal de carboidratos fibrosos por uma deficiência ruminal de nitrogênio (adap. Tedeschi et al., 2000)

Apesar dos sistemas protéicos (NRC, 1996 e CNCPS, 2000) enfatizarem a importância de considerarem em sua estrutura a natureza dinâmica e complexa da nutrição protéica em ruminantes, Galyean (1996) enfatizou que muitas dietas para animais em crescimento e terminação são formuladas baseando-se apenas na porcentagem de PB. O mesmo autor apontou alguns fatores que poderiam alterar a recomendação do teor de proteína na dieta de confinamentos: 1) lotes muito grandes (100 ou mais animais) com grandes variações no tamanho dos animais, implicam em nivelar a exigência de proteína nos animais menores, a fim de não limitar o seu desempenho; 2) a mistura e a distribuição dos alimentos também podem afetar o teor de proteína da dieta, um teor maior de proteína poderia compensar as variações ocorridas no dia a dia; 3) fatores de manejo que contribuem para redução no CMS (ex.: grãos extensivamente processados e ionóforos), necessitando de uma porcentagem superior de proteína na formulação, para 
que as exigências do animal (g/d) não sejam alteradas; 4) efeitos do programa de implantes, particularmente aqueles baseados em combinações de estrógenos e androgênicos (acetato de trembolona), aumentando o crescimento protéico diário. Este efeito é evidenciado principalmente no início da fase de terminação, quando o crescimento protéico é rápido, coincidindo com a fase inicial do implante. Assim, o teor de proteína pode ser reduzido no final do período de terminação sem afetar o desempenho, mas nunca menor que $10 \%$ (Bartle \& Preston, 1994); 5) efeito de tamponamento da amônia no rúmen (Zim, 1995).

Sistemas que consideram a exigência de aminoácido individual e estimam o fluxo duodenal, como CNCPS, são mais prováveis de sucesso na nutrição protéica, do que sistemas que consideram apenas PDR e PND, embora seja difícil determinar o perfil de aminoácidos da PNDR que chega ao duodeno, devido às diferenças no perfil de aminoácidos da PNDR e da proteína original do alimento, os quais geralmente não são conhecidos e a composição dos aminoácidos da proteína microbiana, que também não é constante (Hoover \& Webster, 1996).

Mais estudos são necessários para poder estimar com maior acurácia o fluxo de aminoácidos para o duodeno, pois a exigência do animal é em aminoácidos essenciais absorvidos e não em proteína bruta. Estes estudos devem abordar o teor de proteína bruta da dieta, bem como as frações PDR e PNDR, e a quantidade e o perfil de aminoácidos que chegam ao duodeno, pois a nutrição protéica adequada para maximizar o ganho engloba todos esses fatores simultaneamente.

\subsection{Fontes protéicas}

Os alimentos mais comuns na alimentação de bovinos de corte no Brasil estão apresentados no Quadro 1. A proteína bacteriana e farinha de 
peixe são as que apresentam o melhor perfil de aminoácidos, quando comparadas com a do tecido animal, ambas apresentando uma pequena deficiência de histidina. $O$ farelo de soja e o de algodão apresentam um bom perfil de AA, demonstrando apenas uma pequena deficiência em Metionina. $O$ milho (protenose e grão), sorgo e a polpa cítrica são mais deficientes em Lisina.

\begin{tabular}{|c|c|c|c|c|c|c|c|c|c|c|}
\hline \multirow[b]{2}{*}{ Fontes } & \multicolumn{10}{|c|}{ Aminoácidos $^{2}$} \\
\hline & Met & Lis & Arg & Thr & Leu & Ile & Val & His & Phe & Trp \\
\hline Bactérias & 100 & 100 & 100 & 100 & 100 & 100 & 100 & 81 & 100 & 100 \\
\hline Farinha de peixe & 100 & 100 & 100 & 100 & 100 & 100 & 100 & 93 & 100 & 100 \\
\hline Farelo de soja & 51 & 84 & 100 & 90 & 100 & 100 & 100 & 100 & 100 & 100 \\
\hline Farelo de Algodão & 73 & 68 & 100 & 89 & 89 & 100 & 100 & 100 & 100 & 100 \\
\hline F. de carne e ossos & 43 & 88 & 100 & 65 & 81 & 86 & 91 & 58 & 86 & 100 \\
\hline F. de sangue & 47 & 100 & 100 & 100 & 100 & 48 & 100 & 100 & 100 & 100 \\
\hline F. de pena & 25 & 40 & 100 & 100 & 100 & 100 & 100 & 38 & 100 & 100 \\
\hline Caroço de Algodão & 32 & 60 & 100 & 88 & 94 & 100 & 100 & 100 & 100 & 100 \\
\hline Protenose demilho & 10 & 19 & 96 & 75 & 100 & 10 & 100 & 99 & 100 & 76 \\
\hline Milho grão moído & 57 & 26 & 55 & 72 & 100 & 95 & 93 & 83 & 100 & 76 \\
\hline Sorgo grão moído & 46 & 38 & 100 & 84 & 100 & 100 & 100 & 92 & 100 & 100 \\
\hline Polpa Cítrica & 76 & 58 & 100 & 81 & 69 & 95 & 100 & 76 & 79 & 100 \\
\hline
\end{tabular}

Quadro 1 Escore químico da proteína de diversas fontes em relação a proteína do tecido ${ }^{1}$ (Santos, 1997) 
A combinação de fontes ricas em proteína "bypass", na tentativa de obter uma proteína melhor balanceada em aminoácidos essenciais, tem sido sugerida por diversos nutricionistas. Entretanto, ao combinar, por exemplo, farinha de sangue (alta em Lisina e baixa em Metionina) com protenose de milho (baixa em Lisina e alta em Metionina) não se obtém uma mistura alta nos dois aminoácidos, mas sim uma média, a qual é normalmente inferior à proteína microbiana e, muitas vezes, similar ao farelo de soja .0Santos 1997).

Em uma revisão sobre a utilização de proteína "bypass" para vacas em lactação, Santos et al. (1998) observaram que a suplementação com fontes "bypass" aumentava numericamente a passagem de proteína dietética (proteína total - proteína microbiana) para o intestino, mas diminuía a passagem de proteína microbiana para o intestino delgado, sugerindo que a inclusão de fontes ricas em PNDR na dieta resultaria em limitação de frações nitrogenadas (amônia, peptídeos e aminoácidos) para a síntese de proteína microbiana no rúmen, ficando a passagem de proteína total (proteína microbiana + proteína dietética) para o intestino praticamente constante, principalmente quando a proteína "bypass" substituía o farelo de soja. Os autores também verificaram que a suplementação de proteína "bypass" não teve efeito positivo na passagem de aminoácidos essenciais (AAE) para o intestino, na maioria dos trabalhos analisados, devido à proteína microbiana apresentar qualidade superior à maioria das fontes protéicas ricas em "bypass" em termos do balanço de $A A E$, resultando em desempenho inferior na maioria dos trabalhos com fontes ricas em PNDR, quando comparado ao farelo de soja. Outra possível explicação seria a baixa digestibilidade das fontes de PNDR no intestino delgado (Schwab, 1994).

Sindt et al. (1993), entretanto, sugeriu que a suplementação com PNDR, quando a PM é limitante, pode aumentar a eficiência alimentar, especialmente no início do período alimentar.

Considerando metionina (Met) e lisina (Lis) como os dois aminoácidos (AA) mais limitantes para o crescimento animal (Komarek et 
al.,1983), a PNDR, para ser efetiva, deveria então suprir quantidades adequadas desses dois aa. Por outro lado, a proteína do milho, a maior fonte de PNDR em dietas para terminação, é uma fonte pobre em lisina, sendo assim o primeiro aa limitante para retenção de N. Klemesrud et al. (2000b), com o intuito de determinar o efeito da suplementação de Lys para bezerros com 237 $\mathrm{kg}$ de PV em terminação, avaliaram dietas com alta proporção de milho (45\% de glúten de milho úmido ; $22,5 \%$ de milho de alta umidade; $20 \%$ de milho laminado a seco; $5 \%$ de silagem de milho; $5 \%$ de feno de alfafa; $2,5 \%$ de suplemento mineral e vitamínico; tendo $11,9 \%$ de PB) e com suplementação de Lisina $(0,1,2,3,4,6,8,10$ e $12 \mathrm{~g} / \mathrm{d})$ e Metionina (3,6 g/d). Usando uma análise não linear, os autores observaram um aumento no ganho de peso nos animais que estavam recebendo suplementação com Lisina (uma resposta máxima com 2,56 g/d de Lisina com um ganho de $270 \mathrm{~g} / \mathrm{d}$ a mais que o controle), nos primeiros 56 dias, sendo este período o de maior exigência de proteína metabolizável e maior deposição de proteína. Após os 56 dias, até o final do período, não houve diferença significativa no ganho de peso vivo (GPV), embora tenha ocorrido uma diferença numérica $(200 \mathrm{~g} / \mathrm{d})$ para o tratamento com suplementação de Lisina. Não houve efeito com a suplementação com Metionina no ganho de peso, indicando que dietas ricas em milho não são deficientes em Metionina. No entanto, a resposta no ganho sugere que a Lisina seja o primeiro aminoácido limitante em novilhos terminados com dietas contendo grandes quantidades de proteína de milho, o que pode ser visto na Quadro 1.

Este estudo mostrou que dietas formuladas com valores próximos de PNDR podem resultar em desempenhos completamente diferentes, devido ao impacto da qualidade da fonte protéica, em termos de balanço de aminoácidos essenciais, e que o fator qualidade da fonte protéica, em termos de balanço de aminoácidos, é muito importante, devendo este também ser observado e não apenas o fator degradabilidade. 
Os dados apresentados por Klemesrud et al. (2000a) indicam que dietas de terminação com alta proporção de grãos, provenientes basicamente do milho, o qual contém proteína de baixa degradabilidade ruminal (30 a 70\% de PNDR), apresentam baixa possibilidade de resposta à suplementação com PNDR e/ou aminoácidos protegidos, pois o animal terá um excesso de PM, uma vez que suplementação com PDR faz-se necessária para atender as exigências dos microrganismos ruminais (NRC, 1985; Galyean, 1996; NRC, 1996). A maior possibilidade de resposta estaria relacionada a animais mais jovens, os quais apresentam maior exigência de PM.

A síntese de proteína microbiana no rúmen é a principal fonte de aminoácidos absorvidos pelo animal. O sincronismo da taxa de degradação de carboidratos e proteína (PDR) no rúmen, a adequada quantidade de $\mathrm{N}$ amoniacal, o pH e a taxa de passagem são os principais fatores que afetam a eficiência e produção de proteína microbiana. Dessa forma, alguns autores consideram que as estratégias de suplementação protéica para ruminantes deveriam preocupar-se, primeiramente, com a otimização da síntese de proteína microbiana. Fu et al. (2001), com o objetivo de determinar o teor de PDR que maximizasse a eficiência microbiana (MOEFF), fluxo de nitrogênio microbiano e digestibilidade dos nutrientes no rúmen, avaliaram dietas com teores crescentes de PDR (3,5 a 17,5\% PDR na MS), compostas por milho, caseína e farelo de soja. Os autores verificaram que o aumento da PDR da dieta proporcionou um aumento linear na concentração ruminal de $\mathrm{N}$ amoniacal e peptídeos, entretanto a eficiência microbiana não foi afetada, sugerindo que 1,8 $\mathrm{mM}$ de peptídeos pode maximizar a eficiência microbiana quando $\mathrm{N}$ amoniacal não está deficiente ( $>2 \mathrm{mg} / \mathrm{dL}$ ) e que as exigências de PDR de bactérias fermentadoras de CNE provavelmente são mais baixas do que as comumente utilizadas na formulação das dietas.

Devant et al. (2000) compararam dois teores protéicos (17 e 14\%) e duas degradabilidades ruminais ( $58 \times 42 \%$ da PB para farelo de soja e farelo de soja tratado, respectivamente) em dietas com alta proporção de 
concentrado, não observaram alterações no consumo e ganho de peso diário em novilhas com peso inicial (PI) de 100 e peso final (PF, de $230 \mathrm{~kg}$ ), demonstrando que $14 \%$ de proteína com baixa degradabilidade não limitaram a fermentação ruminal, pois a produção de proteína microbiana não foi alterada.

Ao avaliar três suplementos protéicos com diferentes degradabilbidades ruminais (farinha de penas hidrolisada, farelo de soja e farelo de soja tratado com formaldeído) em dieta volumosa de silagem de sorgo, Fontanelli et al. (2002) verificaram que, apesar da dieta com farinha de pena apresentar os menores coeficientes de digestibilidade, não houve diferença para ganho de peso entre os tratamentos. Os autores concluíram que, para as condições do experimento, utilizando silagem de sorgo e animais com peso inicial de $156 \mathrm{~kg}$, não houve a necessidade de suplementação com PNDR. Da mesma forma, Dutra et al. (1997) não verificaram efeito da fonte de proteína (uma com alta, farelo de soja, e outra com baixa degradabilidade ruminal, farinha de sangue associada com farelo de glúten) sobre a síntese e eficiência de síntese de compostos nitrogenados bacterianos em novilhos ( $\mathrm{Pl}=316 \mathrm{~kg}$ ).

A farinha de peixe, como demonstrado na Quadro 1, é uma boa fonte de aminoácidos essenciais, embora o seu uso seja limitado no Brasil devido à falta de uma farinha de peixe de qualidade, sendo necessária a importação, o que inviabiliza economicamente o seu uso. Zin \& Shen (1998), utilizando dietas com alto teor de grão ( $80 \%$ de milho floculado) com três fontes de proteína (uréia, farelo de soja e farinha de peixe em três teores (1,5, 3,0 e $4,5 \%$ da $\mathrm{MS}$ ) em novilhos cruzados $(\mathrm{Pl}=231 \mathrm{~kg})$, verificaram um aumento linear no ganho de peso vivo (GPV) com o aumento da farinha de peixe, demonstrando que o aumento de $A A E$, provindos da farinha de peixe melhorou a utilização da energia. Entretanto, o GPV proporcionado pelas dietas com farinha de peixe foi menor ao da dieta com uréia, não diferindo do farelo de soja. Os autores concluíram que a maior produção de proteína microbiana no tratamento com uréia e farelo de soja proporcionou um melhor perfil de 
aminoácido e, principalmente, uma maior fermentação ruminal, aumentando o suporte energético (maior produção de AGV) para o animal.

Seis consultores americanos, responsáveis pelo programa de nutrição de 3,6 milhões de cabeças por ano, sugeriram que a proteína "bypass" pode ser importante em algumas circunstâncias, mas que as informações disponíveis são insuficientes para permitir o uso deste fator na formulação de dietas (Galyean, 1996).

A substituição parcial ou total da fonte de $\mathrm{N}$ da dieta por uma fonte de NNP, como a uréia, pode reduzir o custo do $\mathrm{N}$ e da suplementação protéica (Owens \& Zinn, 1988). Revisando dados da literatura, Chalupa (1968) sugeriu que a suplementação com uréia é consistentemente eficiente, quando não ultrapassa $1 / 3$ do nitrogênio total ou $1 \%$ da matéria seca total da dieta. Healy (1995), utilizando dietas com milho floculado e 13\% de PB com suplementação protéica proveniente de combinações de farelo de soja e uréia (100:0; 67:33; 33:67; 0:100), verificaram efeito quadrático para GPV, sendo o maior ganho com 67:33 e a maior conversão alimentar (kg ganho/kg CMS) com a proporção de 33:67.

Knaus et al. (2001), utilizando novilhos ( $\mathrm{PI}=259 \mathrm{~kg}$ ) alimentados com dietas com alta proporção de grãos (milho), avaliaram fontes de proteína: farelo de soja ( $0 \%$ de PNDR), uma combinação de fontes protéicas de subprodutos de origem animal (2,6 e 5,2\% PNDR) e uréia. Os maiores GPV foram obtidos com as dietas contendo farelo de soja $(1,43 \mathrm{~kg} / \mathrm{d})$ e 2,6\% PNDR (1,45 kg/d) em comparação com as dietas com 5,2\% PNDR (1,3 kg/d) e uréia $(1,1 \mathrm{~kg} / \mathrm{d})$. Entretanto, os autores concluíram que o fornecimento da combinação balanceada de AA, oriundo de fontes protéicas de subprodutos de origem animal, não melhorara a eficiência do uso de $\mathrm{N}$ em dietas com alta proporção de grãos provindos do milho, e o fornecimento da uréia, como único suplemento, alcançou igual taxa e eficiência do uso de $\mathrm{N}$.

Devant et al. (2001), ao comparar dietas isonitrogenadas (13,7\% PB) com farelo de soja e uma mistura de protenose de milho mais farinha de 
peixe, com e sem uréia, verificaram um aumento da eficiência $(\mathrm{g} / \mathrm{kg}$ de $\mathrm{MO}$ verdadeiramente digerida) e da produção de proteína microbiana, quando foi adicionada uréia, independente da fonte de proteína verdadeira utilizada. Verifica-se, então, que a utilização de uréia é benéfica, principalmente quando associada a uma fonte de proteína verdadeira, aumentando a eficiência da síntese microbiana em dietas com alto teor de concentrado (Devant et al., 2001). Em dietas com alto teor de concentrado e alta concentração de milho foi demonstrado que os peptídeos (e/ou aminoácidos) do milho deveriam proporcionar uma máxima síntese e eficiência de proteína microbiana, maximizando a produção de proteína microbiana (Milton et al., 1997a; Fu et al., 2001 e Knaus et al., 2001).

Knaus et al. (2001) propuseram que a uréia poderia ser utilizada eficientemente como a única fonte suplementar de $\mathrm{N}$ para suprir as exigências de proteína metabolizável e aminoácidos absorvidos. Baseados nesta idéia, demonstraram ser eficiente o uso do modelo do NRC (1996) para formular dietas, provendo eficiente utilização de $\mathrm{N}$ para animais em crescimento e evitando uma superalimentação com proteína e um retorno desnecessário de $\mathrm{N}$ para o ambiente. 


\section{3 - FARELO DE SOJA EM SUBSTITUIÇÃO À URÉIA EM DIETAS PARA BOVINOS DE CORTE EM CRESCIMENTO}

\section{Resumo}

O objetivo do presente trabalho foi avaliar o aumento no teor de proteína metabolizável da dieta, através da inclusão de farelo de soja em substituição à uréia no desempenho de bovinos machos não castrados em crescimento. Foram utilizados 36 machos, não castrados, (24 Nelore e 12 Canchim), com peso médio inicial de $230 \mathrm{~kg}$ e média de 15 meses de idade. $\mathrm{O}$ delineamento experimental adotado foi o de blocos ao acaso, em que os animais foram agrupados em blocos por raça, peso e idade. O experimento foi conduzido no confinamento do Centro de Produção Intensiva de Bovinos de Corte do Departamento de Zootecnia da ESALQ-USP. Os animais foram alojados em baias cobertas $(3 \times 11 \mathrm{~m})$, com piso, cocho e bebedouro de concretos, sendo distribuídos dois animais por baia, num total de 18 baias. $\mathrm{O}$ período experimental teve duração de 84 dias, divididos em 4 subperíodos de 21 dias. As dietas foram formuladas utilizando o NRC (1996), Nível I, de modo a se obter um balanço de proteína degradável no rúmen (PDR) positivo e energia metabolizável suficiente para ganho de peso diário de 1,31 kg em todos os tratamentos. O tratamento $U$ continha 2,0\% de uréia e 4,1\% de farelo de soja na MS da dieta e proteína metabolizável para GPD de 1,03 kg/animal. O tratamento FSU continha $1,0 \%$ de uréia e $11,5 \%$ de farelo de soja na MS da dieta e proteína metabolizável disponível para GPD de 1,19 kg/animal. O tratamento FS continha $18,8 \%$ de farelo de soja e proteína metabolizável 
disponível para GPD de 1,42 kg/animal. O consumo de MS não foi afetado pelos tratamentos $(P>0,05)$. Entretanto, numericamente, para os animais da raça Canchim, o CMS aumentou até $24 \%$ à medida que se aumentou o teor de proteína metabolizável da dieta. O GPD para o tratamento $U(1,14 \mathrm{~kg} / \mathrm{cab})$ foi menor $(P<0,05)$ que os observados para os tratamentos FSU $(1,26 \mathrm{~kg} / \mathrm{cab})$ e FS (1,28 kg/cab). Numericamente, os efeitos positivos do aumento do teor de proteína metabolizável da dieta no GPD foram bem mais expressivos nos animais da raça Canchim em comparação com o Nelore. No período de 84 dias, não foi possível detectar diferenças $(P>0,05)$ nos ganhos de área de olho de lombo e espessura de gordura entre os tratamentos. Apesar da imprecisão nos valores absolutos, o NRC(1996), nível I, acertou ao predizer um menor desempenho para os animais recebendo a dieta com menor teor de proteína metabolizável (tratamento U).

\section{SOYBEAN MEAL AS A REPLACEMENT FOR UREA ON GROWING BEEF STEERS DIETS}

\section{Summary}

The objective of this trial was the evaluation of increasing diet metabolizable protein by soybean meal inclusion, replacing urea, on growing steers performance. Thirty-six steers, not castrated, (24 Nelore and 12 Canchim), with initial mean weight and age of $230 \mathrm{~kg}$ and 15 months, respectively, were assigned to completely randomized block design, according to genetic group, weight and age. Experiment was conducted at the Departamento de Zootecnia at ESALQ/USP, in the Intensive Beef Steers Center Feedlot. Animals were paired on covered pens $(3 \times 11 \mathrm{~m})$ with concrete floor, feed bulk and waterer, with a total of 18 pens. Experimental period was 84 days, divided on 4 subperiods of 21 days. Diets were formulated according to NRC (1996), Level I, to have a positive rumen degradable protein (RDP) 
balance and metabolizable energy to assure an average daily gain (ADG) of $1.31 \mathrm{~kg}$ to all treatments. Urea treatment $(U)$ contained of $2.26 \%$ urea and $3.92 \%$ soybean meal (DM basis) and metabolizable protein available for an ADG of $1.03 \mathrm{~kg} /$ animal. Soybean meal and Urea treatment (FSU) contained of $1.21 \%$ urea and $10.62 \%$ soybean meal (DM basis) and metabolizable protein available for an ADG of $1.19 \mathrm{~kg} /$ animal. Soybean treatment FS contained of $19.18 \%$ soybean meal in diet DM and metabolizable protein available for an ADG of $1.42 \mathrm{~kg} /$ animal. Dry matter intake (DMI) was not affected by treatments $(P<0.05)$. ADG was lower $(P<0.05)$ for $U$ treatment $(1.14 \mathrm{~kg} / \mathrm{animal})$ as compared to FSU treatment $(1.26 \mathrm{~kg} /$ animal $)$ and $\mathrm{FS}(1.28 \mathrm{~kg} / \mathrm{animal})$. Numerically, the positive effects of increasing metabolizable protein diet on ADG were markedly higher for Canchim than for Nelore animals. There was a trend $(P=0.12)$ for higher feed conversion with increasing soybean meal in the diet. During the 84 days period it was not possible to detect differences on longissimus muscle area and fat thickness among treatments. Level I of NRC (1996) was a good predictor for the lower performance of animals receiving a diet with lower metabolizable protein level (Treatment $U$ ).

\subsection{Introdução}

A formulação de dietas completas para bovinos deve considerar o fornecimento de quantidades adequados de matéria seca (MS), energia liquida, proteína degradável no rúmen (PDR), proteína metabolizável, fibra em detergente neutro (FDN), fibra em detergente ácido (FDA), estrato etéreo (EE), além dos minerais e vitaminas. A capacidade de ganho de peso dos bovinos esta intimamente ligada aos níveis nutricionais aos quais são submetidos e, conseqüentemente, ao consumo de MS. 
Uma das características da dieta que pode influenciar a regulação da ingestão de alimentos é a deficiência ruminal de compostos nitrogenados $(\mathrm{N})$, seja na forma de amônia, aminoácidos ou peptídeos. Quando o suprimento de $\mathrm{N}$, originário do material ingerido ou da reciclagem endógena, não atende aos requisitos microbianos, ocorre limitação do crescimento microbiano (Sniffen et al., 1992).

A concentração e a qualidade da proteína da dieta podem alterar tanto o mecanismo físico como o quimiostático do consumo, nos ruminantes. A redução da proteína abaixo de $7 \%$ e a diminuição da disponibilidade de $\mathrm{N}$ podem reduzir a digestão da fibra e, subseqüentemente, restringir o consumo, em conseqüência da lenta passagem dos alimentos pelo rúmen. Por outro lado níveis elevados de $\mathrm{N}$ podem induzir à toxidez, pelo excesso de liberação de amônia, reduzindo também o consumo de alimento (NRC, 1996).

A quantidade de aminoácidos disponíveis para a absorção deve ser compatível com as necessidades de aminoácidos para atender os requerimentos de mantença e produção dos ruminantes. Quando o objetivo é atingir elevados níveis de produção, ocorre aumento nas exigências protéicas e, para atender esta condição, há necessidade de maximizar a eficiência de síntese de proteína microbiana e suprir quantidade suficiente de proteína não degradável no rúmen, para garantir um suprimento adequado de proteína metabolizável para o animal (Broderick et al., 1991, citados por Valadares Filho, 1995).

De acordo com o NRC (1996), bovinos machos não castrados, na fase de crescimento, alimentados com dietas com $60 \%$ de concentrado na MS, devem ter desempenho inferior quando alimentados com uréia como principal suplemento protéico, em comparação com animais recebendo suplementos protéicos contendo proteína verdadeira como o farelo de soja. Isto seria devido a uma restrição no suprimento de proteína metabolizável nas dietas contendo apenas uréia. 
O objetivo deste trabalho foi avaliar se machos não castrados, confinados durante a fase de crescimento, responderiam a incrementos de proteína metabolizável na dieta, com a adição de farelo de soja, em substituição parcial ou total à uréia.

\subsection{Material e métodos}

\subsubsection{Animais e instalações experimentais}

Foram utilizados 36 machos não castrados (24 Nelore e 12 Canchim), com peso médio inicial de $230 \mathrm{~kg}$ e média de 15 meses de idade.

O experimento foi conduzido nas instalações do Centro de Produção Intensiva de Bovinos de Corte do Departamento de Zootecnia da ESALQ-USP, onde os animais foram alojados em baias $(3 \times 11 \mathrm{~m})$ cobertas, com piso, cocho e bebedouro de concreto, sendo distribuídos dois animais por baia, totalizando 18 baias. O período experimental foi realizado durante o período de agosto a dezembro de 2001.

Os animais foram previamente everminados e receberam uma dose injetável de complexo vitamínico ADE na fase de adaptação as dietas e às instalações experimentais.

\subsubsection{Tratamentos}

Os animais foram alimentados com dietas contendo silagem de capim Tanzânia como volumoso (40\%) e 60\% de concentrado na MS (Quadro 2). Os tratamentos experimentais diferiram quanto ao suprimento de proteína metabolizável para o animal, sendo que nos 3 tratamentos testados, houve suprimento de PDR acima do mínimo exigido pelo NRC(1996) nível I. 
As dietas foram balanceadas utilizando-se o modelo do NRC (1996) nível I. O tratamento $U$ continha 2,26\% de uréia e 3,92 de farelo de soja na MS da dieta e apresentou excesso de 159,4 g/dia de proteína degradável no rúmen (PDR). O tratamento FSU continha 1,21\% de uréia e 10,62 de farelo de soja na MS da dieta e apresentou excesso de 79,1 g/dia de PDR. O tratamento FS continha $19,18 \%$ de farelo de soja como a principal fonte de proteína e praticamente atendeu com exatidão a PDR (excesso de 1g/dia).

Os tratamentos continham energia metabolizável (EM) disponível para GPD de 1,31, 1,31 e 1,33kg e proteína metabolizável disponível para GPD de 1,03; 1,19 e 1,42kg para os tratamentos U, FSU e FS, respectivamente.

As fontes de nitrogênio utilizadas foram: a uréia e farelo de soja. Os tratamentos foram formulados para resultarem em dietas isoprotéicas.

As composições em nutrientes das dietas, estão apresentadas no Quadro 3. A estimativa de desempenho animal (GPD) feita pelo NRC (1996) nível I está demonstrada no Quadro 4.

Os concentrados foram misturados previamente em um misturador horizontal (marca Lucato, capacidade de $250 \mathrm{~kg}$ ). Na hora do fornecimento da alimentação, a silagem de capim e o concentrado, nas suas respectivas proporções, foram misturados utilizando-se um vagão para ração completa (marca Siltomac, com capacidade de $1800 \mathrm{~kg}$ ) e fornecidos como ração completa diariamente (18h), uma vez ao dia. 


\begin{tabular}{|c|c|c|c|}
\hline \multirow[b]{2}{*}{ Ingredientes } & \multicolumn{3}{|c|}{ Tratamentos } \\
\hline & $\mathrm{U}$ & FSU & FS \\
\hline Silagem de Capim Tanzânia ${ }^{2}$ & 39,9 & 39,9 & 39,9 \\
\hline Milho moído & 25,2 & 22,0 & 18,8 \\
\hline Polpa cítrica & 25,2 & 22,0 & 18,8 \\
\hline Farelo de soja & 4,1 & 11,5 & 18,8 \\
\hline Uréia & 2,0 & 1,0 & - \\
\hline MM e Vit. ${ }^{1}$ & 1,9 & 1,9 & 1,9 \\
\hline Sebo & 1,7 & 1,7 & 1,7 \\
\hline
\end{tabular}

Quadro 2 Proporção dos ingredientes (\% da MS) das dietas

\begin{tabular}{lccc}
\hline \multirow{2}{*}{ Composição química } & \multicolumn{3}{c}{ Tratamentos } \\
\cline { 2 - 4 } \multicolumn{1}{c}{ Matéria Seca } & U & FSU & FS \\
Proteína Bruta & 15,63 & 46,63 & 46,63 \\
FDN $^{1}$ & 35,0 & 15,3 & 15,5 \\
FDA $^{2}$ & 22,8 & 35,0 & 35,0 \\
Extrato Etéreo $^{3}$ & 4,4 & 4,2 & 22,9 \\
NDT $^{3}$ & 72,0 & 73,0 & 4,2 \\
\hline
\end{tabular}

${ }^{1}$ Fibra insolúvel em detergente neutro, ${ }^{2}$ Fibra insolúvel em detergente ácido; ${ }^{3}$ Nutrientes digestíveis totais (Kearl, 1982)

Quadro 3 Nutriente das dietas (\% da MS) obtido através da analise laboratorial 


\begin{tabular}{lccc}
\hline \multirow{2}{*}{ Itens } & \multicolumn{3}{c}{ Tratamentos } \\
\cline { 2 - 4 } & $\mathrm{U}$ & $\mathrm{FSU}$ & $\mathrm{FS}$ \\
\hline Bal. PDR, g & 159,4 & 79,1 & 1,0 \\
GPEED, Kg/dia & 1,31 & 1,31 & 1,33 \\
GPEPM, Kg/dia & 1,03 & 1,19 & 1,42 \\
Bal. PM, g/dia & -82 & -34 & 26 \\
\hline $\begin{array}{l}\text { PB = proteína bruta, NDT = nutrientes digestiveis totais, BalPDR = balaço de proteína degradável no rúmen, } \\
\text { GPED = ganho de peso estimado pela energia disponível, GPEPM = ganho de peso estimado pela proteína } \\
\text { metabolizável, Bal. PM = balanço de proteína metabolizável, }\end{array}$ &
\end{tabular}

Quadro 4. Estimativa do NRC (1996, nível I)

\subsubsection{Período experimental}

O período experimental teve duração de 104 dias, sendo os primeiros 20 dias destinados ao processo de adaptação dos animais às instalações e uma dieta intermediária entre os dois tratamentos. O restante do período foi segmentado em quatro subperíodos de 21 dias .

\subsubsection{Colheita dos dados de consumo de matéria seca}

O consumo de matéria seca por animal/dia foi calculado com a diferença da quantidade de MS do alimento oferecido e a quantidade de alimento recusado. A quantidade de MS fornecida foi determinada diariamente com a utilização de vagão para ração completa com balança eletrônica, e a quantidade de sobra foi determinada uma vez por semana, utilizando uma balança digital com precisão de $100 \mathrm{~g}$. As quantidades de alimento oferecidas foram ajustadas diariamente com base nas sobras do dia anterior, objetivando o máximo de cinco por cento de sobra, sendo esta registrada semanalmente. 
Durante o período experimental, foram amostrados os alimentos oferecidos uma vez por semana, os quais foram compostos por subperíodo e tratamento. As amostras foram conservadas congeladas a $-10^{\circ} \mathrm{C}$ para posterior analise.

\subsubsection{Análise bromatológica das dietas e sobras}

Amostras do alimento oferecido e das sobras foram secas em estufas com ventilação forçada à temperatura de $55^{\circ} \mathrm{C}$ por 72 horas e moídas em moinhos tipo Wiley, providos de peneiras com orifício de 2 e em seguida de $1 \mathrm{~mm}$ e, posteriormente, por 12 horas a $105^{\circ} \mathrm{C}$ para determinação de matéria seca de acordo com Silva, (1990); MM, EE e PB de acordo com A.O.A.C. (1990); para FDN, FDA, de acordo com o método de Van Soest et al. (1991), não seqüencial utilizando amilase e sulfito de sódio nas determinações de FDN e para lignina de acordo com Goering \& Van Soest, (1970). A MO foi obtida pela subtração da MM da MS.

\subsubsection{Pesagem dos animais}

Os animais foram pesados no final do período de adaptação e no final de cada subperíodo experimental. As pesagens dos animais foram feitas com jejum alimentar de 12 horas de alimento.

\subsubsection{Leitura de ultra-sonografia}

No início e no final do período experimental, foi medida a área de olho de lombo e espessura de gordura, entre a $12^{\underline{a}}$ e $13^{\underline{a}}$ costela do lado direito de cada animal, através da ultra-sonografia. Foram calculadas as 
diferenças entre a medida do final do experimento e início, tanto da área de olho de lombo quanto da espessura de gordura, para saber o quanto variaram essas medidas no decorrer do experimento.

Para realização da técnica de ultra-sonografia, primeiramente realizou-se a limpeza do local, entre a $12^{\mathrm{a}}$ e $13^{\mathrm{a}}$ costela do lado direito do animal, com escova e raspadeira, para retirada do excesso de pêlos e sujidades; em seguida colocou-se óleo vegetal no dorso do mesmo, para perfeito acoplamento do transdutor com o corpo do animal. O transdutor foi disposto de maneira perpendicular ao comprimento do contrafilé (músculo Longissimus dorsi) entre a $12^{\underline{a}}$ e $13^{\underline{a}}$, local onde é realizado a tomada da imagem ultra-sonográfica.

Durante a leitura da imagem, circundou-se a área de olho de lombo que era visualizada no monitor do aparelho, obtendo-se, assim, uma medida instantânea da mesma, que tinha como unidade o centímetro quadrado $\left(\mathrm{cm}^{2}\right)$. Na mesma imagem mediu-se também a espessura da camada de gordura subcutânea em milímetros $(\mathrm{mm}) \mathrm{O}$ local exato dessa medida foi no terço distal da imagem do músculo. O equipamento de ultra-sonografia utilizado foi o PIEMEDICAL Scanner 200 VET com imagem em tempo real, com transdutor de $3,5 \mathrm{MHz}$, com $18 \mathrm{~cm}$ e uma guia acústica, necessária para o acoplamento do transdutor ao animal.

\subsubsection{Delineamento experimental e análise estatística}

O delineamento experimental utilizado foi $\mathrm{o}$ de blocos casualizados, sendo os blocos arranjados de acordo com peso inicial e raça, tendo dois animais por baia e seis baias por tratamento. Os dados foram analisados pelo procedimento MIXED do programa estatístico SAS (1998). Utilizou-se o seguinte modelo estatístico: 


$$
Y_{i j k}=M+B_{i}+F P_{j}+P+F P x P_{k}+E_{i j k}
$$

Onde:

$$
\begin{aligned}
& M=\text { Média geral } \\
& B_{i}=\text { Efeito do bloco } \\
& F_{j}=\text { Efeito da fonte protéica } \\
& P=\text { Efeito de período } \\
& F P x P_{k}=\text { Interações entre a fonte protéica e o período } \\
& E_{i j k}=\text { Efeito aleatório }
\end{aligned}
$$

Este modelo foi utilizado para analisar todas as variáveis, exceto o consumo de matéria seca, em que se utilizou semana no lugar de período, pois o consumo era determinado semanalmente. O efeito de bloco foi considerado efeito aleatório.

Para as variáveis área de olho de lombo e espessura de gordura, foi utilizado o PROC GLM do pacote estatístico SAS (1998).

As diferenças entre os tratamentos para as diversas variáveis analisadas foram verificadas através do LSMEANS/PDIFF e $5 \%(P \leq 0,05)$ como nível de significância e até $10 \%$ como tendência $(P \leq 0,10)$.

\subsection{Resultados e Discussão}

Os dados de consumo de matéria seca, ganho de peso diário, conversão alimentar, área de olho de lombo e espessura de gordura estão apresentados na Tabela 1. 
Tabela 1. Desempenho de machos não castrados em crescimento confinados com dietas contendo teores crescentes de proteína metabolizável

\begin{tabular}{lccccc}
\hline & $\mathrm{U}$ & $\mathrm{FSU}$ & $\mathrm{FS}$ & $\mathrm{EPM}$ & $\mathrm{P}$ \\
\hline Peso inicial, kg & 243,10 & 230,36 & 237,91 & 9,85 & 0,67 \\
Peso final, kg & 333,75 & 342,75 & 341,75 & 10,99 & 0,82 \\
$\mathrm{CMS}^{1}, \mathrm{~kg} / \mathrm{d}$ & 7,08 & 7,49 & 7,50 & 0,41 & 0,24 \\
$\quad$ \%PV & 2,45 & 2,61 & 2,59 & 0,40 & 0,32 \\
$\quad \mathrm{~g} / \mathrm{kgPV}{ }^{0.75}$ & 91,54 & 104,26 & 117,58 & 8,21 & 0,45 \\
$\mathrm{GPV}^{3}, \mathrm{~kg} / \mathrm{d}$ & 1,14 & 1,26 & 1,28 & 0,05 & 0,03 \\
$\mathrm{CA}^{4}, \mathrm{~kg} \mathrm{MS} / \mathrm{kg}$ ganho & 6,37 & 6,00 & 5,83 & 0,24 & 0,12 \\
$\mathrm{AOL}^{5}, \mathrm{~cm}^{2}$ & 50,03 & 51,36 & 49,70 & -- & -- \\
$\mathrm{GAOL}^{6}, \mathrm{~cm}^{2}$ & 14,94 & 17,78 & 17,90 & 1,81 & 0,44 \\
$\mathrm{EG}^{7}, \mathrm{~mm}$ & 1,85 & 1,81 & 1,91 & -- & -- \\
$\mathrm{GEG}^{8}, \mathrm{~mm}$ & 0,63 & 0,95 & 0,60 & 0,32 & 0,70 \\
\hline
\end{tabular}

${ }^{1} \mathrm{CMS}=$ consumo de matéria seca; ${ }^{2} \mathrm{PV}=$ peso vivo; ${ }^{3} \mathrm{GPV}=$ ganho de peso vivo; ${ }^{4} \mathrm{CA}=$ conversão alimentar; ${ }^{5} \mathrm{AOL}=$ área de olho de lombo; ${ }^{6} \mathrm{GAOL}$ = ganho de área de olho de lombo; ${ }^{7} \mathrm{EG}=$ espessura de gordura $;{ }^{8} \mathrm{GEG}=$ ganho de espessura de gordura.

Os valores de consumo de matéria seca, tanto em $\mathrm{kg} / \mathrm{d}$, porcentagem do peso vivo, quanto em relação ao peso metabólico, não diferiram entre os tratamentos $(P>0,05)$ no presente trabalho.

Os valores de CMS encontrados foram de 7,08; 7,49 e 7,50 kg de MS/dia para os tratamento $\mathrm{U}, \mathrm{FSU}$ e $\mathrm{FS}$, respectivamente, que não estiveram de acordo com o predito pelo NRC (1996, Nível I) que foi de 6,42 kg de MS/dia.

O NRC (1996, Nível I) é conservador no cálculo de exigência em PDR. A quantidade de proteína microbiana produzida no rúmen de acordo com o programa é de $13 \%$ do NDT da dieta. A exigência em PDR é calculada como sendo $100 \%$ da quantidade de proteína microbiana sintetizada. Entretanto, Zinn \& Owens (1983) observaram que em dietas com $80 \%$ de concentrado, a síntese 
microbiana só foi reduzida quando a quantidade de PDR caiu de 80 para $70 \%$ da quantidade de proteína sintetizada no rúmen.

A suplementação protéica pode interferir no consumo de MS, seja pela disponibilidade de frações nitrogenadas para a maximização da fermentação ruminal e síntese microbiana, seja pela quantidade e perfil de aminoácidos disponíveis para a absorção no intestino delgado (NRC, 1996).

No presente trabalho, todas as dietas foram formuladas para conterem balanço de PDR acima do mínimo requerido (zero gramas) pelo NRC (1996) nível I, com o objetivo de evitar restrição na atividade fermentativa ruminal e crescimento microbiano.

Alguns autores quando compararam fontes de nitrogênio não protéico (uréia ou amiréia) com farelo de soja (Thompson et al., 1972; Schmidt et al., 1973, Hussein \& Berger (1995), Teixeira et al., 2000; Knaus et al, 2001 e Oliveira Jr. 2002) ou farelo de algodão (Seixas et al., 1999) também não verificaram alterações no consumo de matéria seca como no presente trabalho.

Perry e Cecava (1995) também relataram que em dietas com alta proporção de alimentos concentrados, especialmente milho, o uso de fontes ricas em PNDR poderá na verdade reduzir a performance animal quando comparada à suplementação com farelo de soja ( rico em PDR). Isto ocorre devido a diminuição da concentração de nitrogênio amoniacal no rúmen, o que limitaria a síntese microbiana. Quando comparado esses dados com os dados obtidos no presente trabalho, podemos observar que o consumo de MS não foi alterado, pois a fonte menos degradavel no rúmen utilizada nos tratamentos foi o farelo de soja, que por sua vez possui grande proporção de PDR. Convém salientar que todas as dietas do presente trabalho possuíam teores de PDR satisfatórios, como demostrado no Quadro 4.

Zinn et al. (2003) observou aumento no CMS de novilhos em crescimento confinados com dietas com $90 \%$ de concentrado com teores crescentes de uréia na MS da dieta de 0\% (10,5\% PB), 0,4\% (11,5\% PB), 0,8\% $(12,5 \%$ PB) e 1,2\% (13,5\% de PB). O efeito positivo em CMS foi linear até a 
dose de $0,8 \%$ de uréia, esse aumento observado, não condis com o encontrado neste trabalho quando aumento a quantidade de PDR. Provavelmente pelas quantidades de proteína bruta da dieta, tendo em vista que neste trabalho a percentagem de PB das dietas foram de aproximadamente 15\%.

Os dados de consumo de MS encontrados no presente trabalho não estão de acordo com os dados encontrados por Zinn \& Shen (1998), Zinn \& Owens (1993), que demostraram uma diminuição de CMS quando se acrescentou PNDR.

No presente estudo, o GPD dos animais foi menor $(P<0,05)$ no tratamento $U$ em comparação aos demais. A diferença observada no ganho de peso diário, nesse experimento, para os tratamentos contendo quantidades maiores de farelo de soja, provavelmente deveu-se ao maior aporte de PNDR chegando ao intestino para complementar a proteína microbiana e assim aumentar a quantidade de proteína metabolizável disponível para o animal.

Restrição de PDR na dieta compromete o GPD principalmente devido ao menor CMS, menor digestão ruminal e menor síntese microbiana, afetando tanto a nutrição protéica como energética, conforme constatado por Zinn et al. (2003). Entretanto o presente trabalho apresentou aumento no GPD com o aumento da PNDR da dieta sem que houvesse alterações no CMS.

As tabelas de requerimentos nutricionais do NRC (1996) apresentam as exigências de proteína metabolizável e de proteína degradável no rúmen para bovinos em crescimento e terminação. De modo geral, de acordo com o NRC (1996), machos não castrados em crescimento, com peso vivo abaixo de $350 \mathrm{~kg}$, alimentados com dietas ricas em energia, e contendo apenas uréia como suplemento protéico, têm seu desempenho limitado por falta de proteína metabolizável. A substituição parcial da uréia por farelo de soja, resultaria em melhor desempenho.

Os dados obtidos neste trabalho concordam com o NRC (1996) que apontou deficiência de proteína metabolizável no tratamento $U$ para novilhos em crescimento em comparação com o tratamento FSU e FS. 
Entretanto, não houve resposta ao suprimento adicional de proteína metabolizável com o tratamento FS vs FSU, conforme proposto pelo NRC (1996). Aparentemente o consumo de energia líquida não foi suficiente para os animais atingirem os GPD proposto pelo NRC, superior à $1,3 \mathrm{~kg}$ e isto pode ter limitado a resposta à suplementacão de proteína metabolizável no tratamento FS em relação ao FSU.

Os ganhos de peso vivo observados de 1,14, 1,26 e 1,28 kg/dia para U, FSU e FS, respectivamente, não estiveram numericamente iguais aos preditos pelo o NRC (1996, Nível I), entretanto o programa apontou um aumento de ganho de peso $(0,92,1,12$ e 1,32 para $U$, FSU e FS, respectivamente) quando se aumentou a quantidade de PNDR. Essa situação foi encontrada no presente trabalho, como demostrado a cima.

Desta forma outros autores também observaram o aumento no GPV quando se acrescenta PNDR (Hussein \& Berger, 1995; Milton et al. 1997b; Zinn \& Shen, 1998; Klemesrud et al 2000a)

Os dados comparativos entre farelo de soja e fontes ricas em PNDR para novilhos em crescimento e terminação têm apresentado resultados menos consistentes que quando se compara fontes de proteína verdadeira com fontes de nitrogênio não protéico.

Perry e Cecava (1995) apontaram que dietas suplementadas com proteína "bypass", não possibilitaram um aumento consistente no fluxo de aminoácidos para o intestino delgado e essa provavelmente seja a explicação pela inconsistência no aumento significativo nas taxas de crescimento.

As chances de sucesso com a inclusão de fontes ricas em PNDR em substituição parcial ou total ao farelo de soja está altamente condicionada à adequação de PDR na dieta. Toda vez que o teor de PDR for limitante devido à adição de fontes ricas em PNDR em substituição ao farelo de soja, a redução no fluxo de proteína microbiana para o intestino contrabalança o maior fluxo de proteína dietária, anulando os benefícios desta prática (Santos et al, 1998). 
Galyean (1996) também apontou que incrementos em desempenho com suplementação de proteína verdadeira só ocorrem quando a quantidade suprida de PDR estiver ajustada. Isto foi observado por Zim e Shen (1998), os quais verificaram melhor GPV com uréia comparado a farelo de soja em dietas deficientes de PDR.

Os dados obtidos de CA $(6,37 ; 6,00$ e 5,83 kgMS / kg ganho para os tratamento U, FSU e FS, respectivamente), não tiveram efeito significativo com o aumento de PNDR, discordando, com isso os dados obtidos por outros autores que obtiveram uma melhor eficiência alimentar quando aumentou a quantidade de PNDR na dieta de novilhos em crescimento. (Milton et al. 1997b e Perry \& Cecava, 1995).

\section{4 - Conclusões}

Os dados obtidos no presente estudo estão de acordo com o NRC (1996) nível I que indicam a necessidade de inclusão de farelo de soja ou outra fonte suplementar de proteína verdadeira na dieta de machos não castrados em crescimento em substituição parcial ou total a uréia, com o objetivo de suprir as exigências em proteína metabolizável. 


\section{FARELO DE SOJA EM SUBSTITUIÇÃO À URÉIA EM DIETAS PARA BOVINOS DE CORTE EMM TERMINAÇÃO}

\section{Resumo}

O presente trabalho teve como objetivo avaliar o aumento de proteína metabolizável, pela inclusão de farelo de soja em substituição a uréia, no desempenho de bovinos machos não castrados em terminação. Foram utilizados quarenta machos (24 Nelore e 16 Canchim), com peso médio inicial de $400 \mathrm{~kg}$ e média de 20 meses de idade. O delineamento experimental utilizado foi o de blocos ao acaso, em que os animais foram agrupados por raça, peso e idade. O experimento foi conduzido no confinamento do Centro de Produção Intensiva de Bovinos de Corte do Departamento de Zootecnia da ESALQ-USP. Os animais foram alojados em baias $(3 \times 11 \mathrm{~m})$ cobertas, com piso, cocho e bebedouro de concretos, sendo distribuídos dois animais por baia, num total de 20 baias. O período experimental teve a duração de 84 dias divididos em 4 subperíodos de 21 dias. As dietas foram formuladas utilizando o NRC (1996), Nível I, de modo a se obter um balanço de proteína degradável no rúmen superior a $80 \mathrm{~g} / \mathrm{dia}$ e energia metabolizável suficiente para ganho de peso diário de $1,40 \mathrm{~kg} / \mathrm{d}$ em todos os tratamentos. O tratamento $U$ continha 2,11\% de uréia na matéria seca (MS) como a principal fonte de nitrogênio da dieta e proteína metabolizável para ganho de peso diário (GPD) de 1,75 
$\mathrm{kg} /$ animal. O tratamento FS continha $7,03 \%$ de farelo de soja e 1,01\% de uréia na MS da dieta, proteína metabolizável disponível para GPD de 2,09kg/animal. O consumo de MS (CMS) não foi afetado pelos tratamentos ( $P>0,05)$, com valores de $12,1 \mathrm{Kg}$ de MS/cab.dia para o tratamento $\mathrm{U}$ e $12,5 \mathrm{Kg}$ de MS/cab.dia para o tratamento $F S$. O GPD foi maior $(P<0,05)$ para os animais que receberam o tratamento com maior quantidade de proteína metabolizável (FS; GPD $=1,46 \mathrm{~kg} / \mathrm{d}$ ) em relação aos animais que receberam o tratamento com menor quantidade de proteína metabolizável, (U; GPD = 1,29kg/d).

\section{SOYBEAN MEAL AS A REPLACEMENT FOR UREA ON FINISHING BEEF STEERS DIETS}

\section{Summary}

The objective of this trial was the evaluation of increasing diet metabolizable protein by soybean meal inclusion, replacing urea, on finishing steers performance. Forty steers, not castrated, (24 Nelore and 16 Canchim), with initial mean weight and age of $400 \mathrm{~kg}$ and 20 months, respectively, were assigned to completely randomized block design, according to genetic group, weight and age. Experiment was conducted at the Departamento de Zootecnia at ESALQ/USP, in the Intensive Beef Steers Center Feedlot. Animal were paired on covered pens $(3 \times 11 \mathrm{~m})$ with concrete floor, feed bulk and waterer, with a total of 20 pens. Experimental period was 84 days, divided on 4 subperiods of 21 days. Diets were formulated according to NRC (1996), Level I to have a rumen degradable protein (PDR) balance higher than $80 \mathrm{~g} / \mathrm{d}$ and metabolizable energy to assure a average daily gain (ADG) of $1.40 \mathrm{~kg}$ on all 
treatments. Urea treatment $(U)$ contained $2.11 \%$ urea on diet DM as the main source of protein and metabolizable protein available for an ADG of 1.75 $\mathrm{kg} /$ animal. Soybean meal treatment (FS) contained $7.03 \%$ soybean meal and $1.01 \%$ urea in diet DM and metabolizable protein available for an ADG of 2.09 $\mathrm{kg} / \mathrm{animal}$. Dry matter intake $(\mathrm{DMl})$ was not affected by treatments $(P<0.05)$, with values of $12.1 \mathrm{~kg}$ and $12.5 \mathrm{~kg} \mathrm{DM} / \mathrm{d}$ for $U$ and FS Treatment, respectively. ADG was higher $(P<0.05)$ for animals receiving the higher metabolizable protein diet (FS: $1.46 \mathrm{~kg} / \mathrm{d}$ ) as compared to the lower metabolizable protein diet (U: $1.29 \mathrm{~kg} / \mathrm{d})$.

\subsection{Introdução}

A formulação de dietas completas para bovinos deve considerar o fornecimento de quantidades adequadas de matéria seca (MS), energia líquída, proteína degradável no rúmen (PDR), proteína metabolizável, fibra em detergente neutro (FDN), fibra em detergente ácido (FDA), estrato etéreo (EE), além dos minerais e vitaminas. A capacidade de ganho de peso dos bovinos está intimamente ligada aos níveis nutricionais aos quais são submetidos e, conseqüentemente, ao consumo de MS.

Uma das características da dieta que pode influenciar a regulação da ingestão de alimentos é a deficiência ruminal de compostos nitrogenados $(\mathrm{N})$, seja na forma de amônia, aminoácidos ou peptídeos. Quando o suprimento de $\mathrm{N}$, originário do material ingerido ou da reciclagem endógena, não atende aos requisitos microbianos, ocorre limitação do crescimento microbiano (Sniffen et al., 1992) e depressão da digestão da parede celular (Wilson \& Kennedy, 1996). O resultado final é geralmente a diminuição do consumo de matéria seca.

A nutrição protéica de bovinos evoluiu do conceito de proteína bruta (NRC, 1984), sem diferenciar as exigências da população microbiana das exigências do ruminante, para o atual estágio em que as exigências dos 
microrganismos ruminais (proteína degradável no rúmen) e do bovino (proteína metabolizável) são necessárias para o balanceamento da dieta (NRC, 1996).

Os aminoácidos disponíveis para serem absorvidos no intestino são provenientes da digestão de três fontes de proteína, que são a proteína microbiana, a proteína da dieta não degradada no rúmen e a proteína endógena (NRC, 1996). Para efeito de cálculo, o NRC (1996) desconsidera a proteína endógena.

O valor que uma fonte protéica possui, para aumentar a performance dos ruminantes é determinado pela sua habilidade em fornecer aminoácidos limitantes para o intestino delgado e pela capacidade de disponibilizar nitrogênio para a microbiota ruminal (Titgemeyer et al., 1989).

A quantidade de aminoácidos disponíveis para a absorção deve ser compatível com as necessidades de aminoácidos para atender os requerimentos de mantença e produção dos ruminantes. Quando o objetivo é atingir elevados níveis de produção, ocorre aumento nas exigências protéicas e, para atender essa condição, há necessidade de maximizar a eficiência de síntese de proteína microbiana e suprir quantidade suficiente de proteína não degradável no rúmen, para garantir um suprimento adequado de proteína metabolizável para o animal (Broderick et al., 1991, citados por Valadares Filho, 1995).

De acordo com o NRC (1996), bovinos machos não castrados, na fase de terminação, alimentados com dietas ricas em concentrado (acima de $60 \%$ de concentrado na MS), têm sua exigência em proteína metabolizável atendida apenas com a suplementação de uréia, não havendo a necessidade de fontes suplementares de proteína verdadeira como farelo de soja ou algodão, por exemplo. Entretanto, dados recentes de pesquisa têm mostrado que animais não castrados ou castrados implantados respondem à suplementação com farelo de soja em dietas com 60 a 90\% de concentrado (Bandt Jr., et al., 1995; Oliveira Jr., 2002; Santos, comunicação pessoal, 2003). 
O objetivo deste trabalho foram avaliar se machos não castrados, confinados durante a fase de terminação, responderiam a incrementos de proteína metabolizável na dieta, com a adição de farelo de soja, em substituição à uréia, em dietas contendo $70 \%$ de concentrado e $30 \%$ de silagem de capim tropical.

\subsection{Material e métodos}

\subsubsection{Animais e instalações experimentais}

Foram utilizados 40 machos não castrados (24 Nelore e 16 Canchim), com peso médio inicial de $383 \mathrm{~kg}$ para raça Nelore e $420 \mathrm{~kg}$ para raça Canchim com uma idade média de 20 meses para as duas raças.

O experimento foi conduzido nas instalações no Centro de Produção Intensiva de Bovinos de Corte do Departamento de Zootecnia da ESALQ-USP, onde os animais foram alojados em baias $(3 \times 11 \mathrm{~m})$ cobertas, com piso, cocho e bebedouro de concreto, sendo distribuídos dois animais por baia, em um total de 20 baias.

Os animais foram previamente everminados e receberam uma dose injetável de complexo vitamínico $A D E$ na fase de adaptação às dietas e às instalações experimentais.

\subsubsection{Tratamentos}

Os animais foram alimentadas com dietas contendo silagem de capim Tanzânia como volumoso (30\%) e 70\% de concentrado na MS (Quadro 5). As dietas foram formuladas utilizando o NRC (1996), Nível I, de modo a se obter um balaço de proteína degradável no rúmen superior a $80 \mathrm{~g} / \mathrm{dia}$ e energia 
metabolizável suficiente para ganho de peso diário de 1,40 kg/d em todos os tratamentos. O tratamento $U$ continha 2,11\% de uréia na matéria seca (MS), como a principal fonte de nitrogênio da dieta, e proteína metabolizável para ganho de peso diário (GPD) de $1,75 \mathrm{~kg} / \mathrm{animal}$. O tratamento FS continha $7,03 \%$ de farelo de soja e 1,01\% de uréia na MS da dieta, proteína metabolizável disponível para GPD de 2,09kg/animal

A composição em ingredientes e nutrientes das dietas estão apresentadas nos Quadros 5 e 6.

Os concentrados foram misturados previamente em um misturador horizontal (marca Lucato, capacidade de $250 \mathrm{~kg}$ ). Na hora do fornecimento da alimentação, a silagem de capim e o concentrado, nas suas respectivas proporções, foram misturados utilizando-se um vagão para ração completa (marca Siltomac, com capacidade de $1800 \mathrm{~kg}$ ) e fornecidos como ração completa diariamente (18:00h), uma vez ao dia.

\begin{tabular}{|c|c|c|}
\hline \multirow[b]{2}{*}{ Ingredientes } & \multicolumn{2}{|c|}{ Tratamentos } \\
\hline & $\cup$ & FS \\
\hline Silagem de Tanzânia ${ }^{2}$ & 30,12 & 30,12 \\
\hline Milho moído & 48,39 & 42,37 \\
\hline Farelo de soja & - & 7,03 \\
\hline Polpa cítrica peletizada & 15,06 & 15,06 \\
\hline Uréia & 2,11 & 1,10 \\
\hline Sebo & 2,71 & 2,71 \\
\hline MM e Vit ${ }^{1}$ & 1,61 & 1,61 \\
\hline
\end{tabular}

Quadro 5 Porção dos ingredientes (\% da MS) das dietas 


\begin{tabular}{lcc}
\hline \multirow{2}{*}{ Composição química } & \multicolumn{2}{c}{ Tratamentos } \\
\cline { 2 - 3 } & $\mathrm{U}$ & $\mathrm{FS}$ \\
\hline Matéria Seca & 49 & 49 \\
Proteína Bruta & 13,6 & 13,6 \\
FDN $^{1}$ & 28,0 & 28,0 \\
FDA $^{2}$ & 22,9 & 22,9 \\
Extrato Etério $^{3}$ & 4,0 & 4,1 \\
NDT $^{3}$ & 76 & 76
\end{tabular}

${ }^{1}$ Fibra insolúvel em detergente nutro, ${ }^{2}$ Fibra insolúvel em detergente ácido;

${ }^{3}$ Nutrientes digestiveis totais (Kearl, 1982)

Quadro 6 Nutrientes das dietas (\% da MS)

\begin{tabular}{lcc}
\hline \multirow{2}{*}{ Itens } & \multicolumn{2}{c}{ Tratamentos } \\
\cline { 2 - 3 } & $\mathrm{U}$ & $\mathrm{FS}$ \\
\hline Bal. PDR, g & 126,2 & 15,9 \\
GPEED, Kg/dia & 1,41 & 1,42 \\
GPEPM, Kg/dia & 1,75 & 2,09 \\
Bal. PM, g/dia & 87 & 170
\end{tabular}

PB = proteína bruta, NDT = nutrientes digestiveis totais, BalPDR = balaço de proteína degradável no rúmen, GPEED = ganho de peso estimado pela energia disponível, GPEPM = ganho de peso estimado pela proteína metabolizável, Bal. PM = balanço de proteína metabolizável,

Quadro 7. Estimativa do NRC (1996, nível I) 


\subsubsection{Período experimental}

O período experimental teve duração de 84 dias, sendo os primeiros 21 dias destinados ao processo de adaptação dos animais às instalações e às dietas experimentais. O restante do período foi segmentado em três subperíodos de 21 dias .

\subsubsection{Colheita de dados referentes ao consumo de matéria seca}

O consumo de matéria seca por animal/dia foi obtido através da diferença entre a quantidade de MS do alimento oferecida e a quantidade de sobra recusada a cada semana. A quantidade de MS fornecida foi determinada diariamente com a utilização de balança eletrônica do vagão para ração completa e a quantidade de sobra foi feita a cada semana, utilizando-se uma balança digital com precisão de $100 \mathrm{~g}$. As quantidades de alimento oferecidas foram ajustadas diariamente com base nas sobras do dia anterior, objetivando o máximo de cinco por cento de sobra, sendo esta registrada semanalmente.

Durante o período experimental, foram amostradas as sobras e os alimentos oferecidos uma vez por semana, as quais foram compostas por subperíodo e tratamento e foram conservadas congeladas a $-10^{\circ} \mathrm{C}$ para posterior análise.

\subsubsection{Análise bromatológica das dietas e sobras}

Amostras do alimento oferecido e das sobras foram secas em estufas com ventilação forçada à temperatura de $55^{\circ} \mathrm{C}$ por 72 horas e moídas em moinhos tipo Wiley, providos de peneiras com orifício de 2 e em seguida de $1 \mathrm{~mm}$ e, posteriormente, por 12 horas a $105^{\circ} \mathrm{C}$ para determinação de matéria seca de acordo com Silva, (1990); MM, EE e PB de acordo com A.O.A.C. (1990); para FDN, FDA, de acordo com o método de Van Soest et al. (1991), 
não seqüencial utilizando amilase e sulfito de sódio nas determinações de FDN e para lignina de acordo com Goering \& Van Soest, (1970). A MO foi obtida pela subtração da MM da MS.

\subsubsection{Pesagem dos animais}

Os animais foram pesados no final do período de adaptação e no final de cada subperíodo experimental. As pesagens dos animais foram feitas com jejum de 12 horas de alimento.

\subsubsection{Leitura de ultra-sonografia}

No início e no final do período experimental, foi medida a área de olho de lombo e espessura de gordura, entre a $12^{\underline{a}}$ e $13^{\underline{a}}$ costela do lado direito de cada animal, através da ultra-sonografia. Foram calculadas as

diferenças entre a medida do final do experimento e início, tanto da área de olho de lombo quanto da espessura de gordura, para saber o quanto variaram essas medidas no decorrer do experimento.

Para realização da técnica de ultra-sonografia, primeiramente realizou-se a limpeza do local, entre a $12^{\underline{a}}$ e $13^{\text {a }}$ costela do lado direito do animal, com escova e raspadeira para retirada do excesso de pêlos e sujidades; em seguida colocou-se óleo vegetal no dorso do mesmo para perfeito acoplamento do transdutor com o corpo do animal. O transdutor foi disposto de maneira perpendicular ao comprimento do contrafilé (músculo Longissimus dorsi) entre a $12^{-}$e $13^{\underline{a}}$, local onde é realizada a tomada da imagem ultra-sonográfica.

Durante a leitura da imagem, circundou-se a área de olho de lombo que era visualizada no monitor do aparelho, obtendo-se, assim, uma medida instantânea da mesma. Essa medida tinha como unidade o centímetro quadrado $\left(\mathrm{cm}^{2}\right)$. Na mesma imagem mediu-se também a espessura da camada 
de gordura subcutânea em milímetros ( $\mathrm{mm}$ ). O local exato dessa medida foi no terço distal da imagem do músculo. O equipamento de ultra-sonografia utilizado foi o PIEMEDICAL Scanner 200 VET com imagem em tempo real, com transdutor de $3,5 \mathrm{MHz}$, com $18 \mathrm{~cm}$ e uma guia acústica, necessária para o acoplamento do transdutor ao animal.

\subsubsection{Delineamento experimental e análise estatística}

O delineamento experimental utilizado foi $\mathrm{o}$ de blocos casualizados, sendo os blocos arranjados de acordo com peso inicial e raça, tendo dois animais por baia e 10 baias por tratamento. Os dados foram analisados pelo procedimento MIXED do programa estatístico SAS (1988). Utilizou-se o seguinte modelo estatístico:

$$
Y_{i j k}=M+B_{i}+F P_{j}+P+F P x P_{k}+E_{i j k}
$$

Onde:

$$
\begin{aligned}
& M=\text { Média geral } \\
& B_{i}=\text { Efeito do bloco } \\
& F P_{j}=\text { Efeito da fonte protéica } \\
& P=\text { Efeito de Período } \\
& F P x P_{k}=\text { Interações entre a fonte protéica e o período } \\
& E_{i j k}=\text { Efeito aleatório }
\end{aligned}
$$

Este modelo foi utilizado para analisar todas as variáveis, exceto o consumo de matéria seca, em que se utilizou semana no lugar de período. 0 efeito bloco foi considerado efeito aleatório. 
As diferenças entre os tratamentos para as diversas variáveis analisadas foram verificadas através do teste de $F$ e $5 \%(P \leq 0,05)$ como nível de significância e até $10 \%$ como tendência $(P \leq 0,10)$.

\subsection{Resultados e Discussão}

Os dados de consumo de matéria seca, ganho de peso diário, conversão alimentar, área de olho de lombo e espessura de gordura estão apresentados na Tabela 3.

Tabela 3. Desempenho de bovinos de corte em terminação confinados e suplementados com fontes de proteína

\begin{tabular}{|c|c|c|c|c|}
\hline & $U$ & FS & EPM & $P$ \\
\hline Peso inicial, kg & 389,30 & 393,80 & 3,60 & 0,385 \\
\hline Peso final, $\mathrm{kg}$ & $464,40^{\mathrm{a}}$ & $486,00^{b}$ & 5,77 & 0,013 \\
\hline $\mathrm{CMS}^{1}, \mathrm{~kg} / \mathrm{d}$ & 12,1 & 12,5 & 0,4 & 0,204 \\
\hline$\% \mathrm{PV}^{2}$ & 2,8 & 2,9 & 0,22 & 0,358 \\
\hline $\mathrm{g} / \mathrm{kgPV}^{0.75}$ & 128,96 & 130,06 & 11,08 & 0,467 \\
\hline $\mathrm{GPV}^{3}, \mathrm{~kg} / \mathrm{d}$ & $1,29^{b}$ & $1,46^{a}$ & 0,05 & 0,019 \\
\hline $\mathrm{CA}^{4}, \mathrm{~kg} \mathrm{MS} / \mathrm{kg}$ ganho & 9,16 & 8,91 & 0,56 & 0,343 \\
\hline $\mathrm{AOL}, \mathrm{cm}^{2}$ & 83,38 & 80,34 & ---- & ---- \\
\hline $\mathrm{GAOL}^{5}, \mathrm{~cm}^{2}$ & 15,8 & 16,0 & 1,50 & 0,890 \\
\hline $\mathrm{EG}, \mathrm{cm}^{2}$ & 3,81 & 3,59 & ---- & ---- \\
\hline $\mathrm{GEG}^{6}, \mathrm{~mm}$ & 1,58 & 1,39 & 0,23 & 0,520 \\
\hline
\end{tabular}


Os valores de consumo de matéria seca, tanto em $\mathrm{kg} / \mathrm{d}$, porcentagem do peso vivo, quanto em relação ao peso metabólico, não diferiram entre os tratamentos $(P>0,05)$.

A suplementação protéica pode interferir no consumo de MS, seja pela disponibilidade de frações nitrogenadas para a maximização da fermentação ruminal e síntese microbiana, seja pela quantidade e perfil de aminoácidos disponíveis para a absorção no intestino delgado (NRC, 1996).

A deficiência de amônia ruminal pode promover uma diminuição de consumo devido à menor atividade fermentativa no rúmen (Orskov, 1988). Segundo Russel et al. (1992), e Tedeschi et al. (2001), as bactérias fermentadoras de carboidratos fibrosos, utilizam amônia com única fonte de nitrogênio, sendo estas altamente prejudicadas quando ocorre uma deficiência de nitrogênio degradável no rúmen, levando a um menor desaparecimento dos carboidratos fibrosos.

Sindt et al. (1993) relataram que dietas para bovinos em confinamento, com alta proporção de milho, podem ser deficientes em PDR, devido ao alto escape da sua fração protéica, que é de aproximadamente $60 \%$ em relação a proteína bruta.

Perry e Cecava (1995) também relataram que em dietas com alta proporção de alimentos concentrados, especialmente milho, o uso de fontes ricas em PNDR poderá na verdade reduzir a performance animal quando comparada à suplementação com farelo de soja ( rico em PDR). Isto ocorre devido a diminuição da concentração de nitrogênio amoniacal no rúmen, o que limitaria a síntese microbiana.

Oliveira Jr (2002), também relataram que alterações negativas no consumo ocorrem quando a quantidade ou degradabilidade ruminal da proteína dietética não são suficientes para produzirem concentrações adequadas de amônia ruminal, sendo importante conhecer as frações protéicas da proteína dietética. 
Em dietas ricas em cevada floculada, Zinn (1995) observou um aumento linear no CMS quando acrescentou até 1,2\% da MS da dieta para novilhos Holandeses. O autor atribuiu essa resposta ao poder tampão da uréia nas primeiras horas após a alimentação.

Zinn et al. (2003) observaram aumento no CMS de novilhos em crescimento confinados com dietas com $90 \%$ de concentrado com teores crescentes de uréia na MS da dieta de $0 \%$ (10,5\% PB), 0,4\% (11,5\% PB), 0,8\% $(12,5 \%$ PB) e $1,2 \%$ ( $13,5 \%$ de $\mathrm{PB})$. O efeito positivo em CMS foi linear até a dose de $0,8 \%$ de uréia.

No presente trabalho, todas as dietas foram formuladas pelo NRC (1996) nível I. As dietas continham balanço positivo de PDR (80 gramas ou mais), com o objetivo de evitar restrição na atividade fermentativa ruminal e crescimento microbiano.

No NRC (1996) a quantidade de proteína microbiana produzida no rúmen é de $13 \%$ do NDT da dieta. A exigência em PDR é calculada como sendo $100 \%$ da quantidade de proteína microbiana sintetizada. Entretanto, os dados de Zinn \& Owens (1983) e Zinn \& Shein (1998) sugerem que o NRC (1996) é conservador quanto a essa recomendação. Esses autores observaram que em dietas com $80 \%$ de concentrado, a síntese microbiana não foi reduzida com fornecimento de PDR de $80 \%$ da quantidade de proteína sintetizada no rúmen.

Ao contrário do sugerido pelo NRC (1996), em alguns trabalhos a inclusão de doses crescentes de uréia à uma dieta basal, com teores de PB ao redor de 8 a 9\% na MS, ou seja, deficientes em PDR (NRC,1996), tem causado redução ao invés de aumento no CMS ou ausência de efeito.

Milton et al. (1997a), estudaram o efeito de doses crescentes de uréia ( $0 ; 0,5 ; 1,0$ e 1,5\% da MS) em dietas para novilhos em terminação. Houve redução média de 3,6 \% no consumo de MS dos animais recebendo uréia na dieta do que para animais que não receberam uréia. Segundo os autores, essa diminuição de consumo pode ser em conseqüência da maior fermentação do 
amido na dieta. Neste caso, apesar da ausência de efeito positivo da adequação de PDR da dieta no CMS, tanto a fermentação ruminal, como o GPD foram maiores nas dietas com uréia que na dieta controle.

Shain et al. (1998) trabalharam com a inclusão de uréia $(0,0,88$, 1,34 e $1,96 \%$ da MS) em dietas contendo alto nível de milho floculado para bovinos castrados em terminação ( $343 \mathrm{~kg}$ ) e não observaram aumento no consumo de matéria seca com a inclusão de uréia em relação à dieta controle.

Quando não há limitação de PDR, a maioria dos trabalhos têm mostrado ausência de efeito no CMS, quando suplementos protéicos como farelo de soja e de algodão são comparados à uréia.

Knaus et al. (2000) forneceram dietas com $85 \%$ de concentrado para novilhos confinados e compararam a dieta controle (somente uréia como suplemento protéico) com dietas contendo teores crescentes de PNDR, através da adição de farelo de soja ou da mistura de farelo de soja com farinha de peixe, farinha de carne e ossos, farinha de sangue e farinha de penas. A dieta controle (uréia) continha $13,5 \%$ de PB e estava deficiente em peptídeos conforme o NRC (1996) nível II. A dieta com farelo de soja (13,9\% de PB), estava adequada em $\mathrm{N}$ bacteriano e peptídeos. As 2 dietas com as fontes de proteína de origem animal estavam adequadas em $\mathrm{N}$ bacteriano mas deficientes em peptídeos. O consumo de MS não foi afetado pelos tratamentos.

Milton et al. (1997b), compararam o fornecimento de uréia, farelo de soja e farelo de algodão em dietas contendo milho laminado, para novilhos em terminação. Os autores não observaram diferenças no CMS entre os animais que receberam os diferentes tratamentos.

Vários outros autores quando compararam fontes de nitrogênio não protéico (uréia ou amiréia) com farelo de soja (Thompson et al., 1972; Schmidt et al., 1973 e Teixeira et al., 2000) ou farelo de algodão (Seixas et al., 1999) também não verificaram alterações no consumo de matéria seca como no presente trabalho. 
Entretanto, Oliveira et al (2002) observaram maior CMS em dietas com farelo de soja comparadas a dietas com uréia, para novilhos em terminação.

Coomer et al. (1993) compararam farelo de soja, farelo de soja tostada e farelo de glúten (60\%) para novilhos de ano em dietas com $70 \%$ de concentrado e 15 a 16\% de PB. Não houve diferença no CMS entre as dietas com farelo de soja e as dietas com fontes ricas em PNDR. Dietas com teores de PB entre 15 a 16\%, dificilmente são deficientes em PDR, mesmo quando se utiliza fontes ricas em PNDR.

O GPD dos animais foi maior $(P<0,05)$ no tratamento $F S$ em comparação ao tratamento $U$. A diferença observada no ganho de peso diário, nesse experimento, para o tratamento contendo farelo de soja, provavelmente deveu-se ao maior aporte de PNDR chegando ao intestino para complementar a proteína microbiana e assim aumentar a quantidade de proteína metabolizável disponível para o animal (NRC, 1996). Também existe a possibilidade de a síntese microbiana ter sido maior no tratamento farelo de soja devido à maior disponibilidade de peptídeos e aminoácidos no rúmen (Russel et al, 1992).

As tabelas de requerimentos nutricionais do NRC (1996) apresentam as exigências de proteína metabolizável e de proteína degradável no rúmen para bovinos em crescimento e terminação. De modo geral, de acordo com o NRC (1996), machos não castrados em terminação, com peso vivo superior de $350 \mathrm{~kg}$, alimentados com dietas ricas em energia, e contendo apenas uréia como suplemento protéico, não apresentariam limitações em seu desempenho pôr falta de proteína metabolizável. A substituição parcial da uréia por farelo de soja, não deveria afetar o desempenho dos animais de acordo com este programa.

Conforme mencionado anteriormente, as dietas foram formuladas para suprirem pelo menos $80 \mathrm{~g}$ de PDR acima da recomendação do NRC (1996) nível I, para evitar restrições na síntese microbiana. 
Shain et al. (1998) forneceram para novilhos de ano castrados e confinados, dietas contendo milho laminado à seco suplementadas com diferentes níveis de uréia $(0 ; 0,88 ; 1,34 ; 1,96 \%$ da MS) como único suplemento protéico. Os teores de PB foram 9,7; 12,0; 13.5 e 15\% da MS respectivamente. Os animais que receberam dietas com teores mais elevados de PB que a dieta controle, através da adição de uréia, foram $5,4 \%$ mais eficientes e ganharam peso $6,6 \%$ mais rápido que os animais que não consumiram uréia. Concluiu-se que dietas à base de milho que não continham uréia, foram deficientes em PDR e que o fornecimento de uréia até o nível de $0,88 \%$ da MS proporcionou incremento na performance.

Entretanto, o NRC (1996) nível I não diferencia as diferentes frações nitrogenadas na PDR, isto é amônia, aminoácidos e peptídeos. É sabido que a síntese microbiana é maximizada quando uma combinação dessas 3 frações nitrogenadas estão disponíveis no rúmen em quantidades adequadas (Russel et al, 1992). O NRC (1996) nível II, utiliza o modelo dinâmico do sistema de Cornell, conforme descrito por Russel et al. (1992). O sistema de Cornell (CNCPS) fraciona a PDR nas 3 frações acima descritas e inclui um fator de correção para a síntese microbiana em função da concentração ruminal de peptídeos.

A fração protéica degradável do farelo de soja (35\% segundo o NRC (1996)), além de fornecer amônia para síntese de proteína microbiana, disponibiliza peptídeos, aminoácidos e outros fatores de crescimento que incrementam a síntese microbiana e talvez esta fração seja requerida para que ocorra a fermentação ótima de dietas com alto teor de grãos (Zinn e Owens 1983; Milton et al., 1997b). Além disto, o farelo de soja pode aumentar o fornecimento de proteína metabolizável não só através do maior fluxo de proteína microbiana como pelo aporte de proteína não degradável no rúmen ao intestino (MILTON et al., 1997b).

Quando as dietas utilizadas neste experimento foram analisadas no NRC(1996) nível II, pôde ser constatado que a dieta U tinha um balanço 
ruminal de peptídeos de $-59 \mathrm{~g}$, contra - $25 \mathrm{~g}$ para o tratamento FS. Este valor mais negativo para o tratamento $U$ pode ter resultado em menor síntese microbiana e assim menor fluxo de proteína metabolizável para o intestino em comparação ao FS. Além de uma possível maior síntese microbiana, o tratamento com FS também deve ter propiciado um maior fluxo de PNDR para o intestino e assim, estes dois fatores permitiram um maior fluxo de proteína metabolizável para o intestino.

Milton et al. (1997b), compararam o fornecimento de uréia, farelo de soja e farelo de algodão em dietas contendo milho laminado, para novilhos em terminação. Os autores observaram que os animais que receberam farelo de soja foram $9 \%$ mais eficientes do ponto de vista alimentar e ganharam peso 13\% mais rápido que os suplementados com uréia. Os parâmetros metabólicos indicaram maior fluxo de nitrogênio microbiano, bem como maior eficiência da síntese de proteína microbiana para o farelo de soja. Os dados de ganho de área de olho de lombo e ganho de espessura de gordura da carcaça não sofreram alterações com os tratamentos.

A substiuição de fontes como farelo de soja e de algodão por fontes ricas em PNDR em dietas para bovinos em terminação tem sido pouco estudada. Coomer et al. (1993) verificaram que aumentando o teor de PNDR, por meio da adição de farelo de soja aquecido e farelo de glúten de milho, houve incremento no fluxo de proteína bruta, aminoácidos e aminoácidos essenciais para o abomaso bem como uma maior absorção no intestino delgado de novilhos alimentados com estes suplementos em comparação ao farelo de soja.

Entretanto, de acordo com o NRC (1996) esta prática não resultaria em melhora no desempenho, uma vez que a inclusão de farelo de soja ou de algodão já resultariam em suprimento adequado ou até mesmo excessivo de proteína metabolizável.

De acordo com o levantamento feito por Galyean ( 1996), nos confinamentos comerciais americanos, fontes suplementares ricas em PNDR 
não são utilizadas em dietas de terminação, em substituição parcial ou total ao farelo de soja e uréia.

Os dados de ganho de área de olho de lombo e ganho de espessura de gordura da carcaça não sofreram alterações com os tratamentos $(P>0,05)$. Seria esperado um maior ganho de $A O L$ no tratamento $F S$ em função do maior GPD neste tratamento.

Milton et al. (1997c) verificaram que o peso da carcaça quente e o seu rendimento, em novilhos de ano cruzados suplementados em confinamento com diferentes níveis de uréia, responderam de forma significativa à adição de uréia a dieta. O peso da carcaça dos animais que receberam uréia foi $6,6 \mathrm{~kg}$ maior dos que não receberam uréia. A área de Longissimus dorsi não foi afetado pelo nível de uréia. A espessura de gordura subcutânea aumentou linearmente ao nível de uréia adicionado à dieta.

Milton et al. (1997a) ao compararem novilhos de ano castrados submetidos a dietas contendo uréia mais de farinha de sangue e farelo de glúten de milho, ou farelo de soja mais farinha de sangue e farelo de glúten de milho, observaram que os animais que receberam a dieta que continha uréia, apresentaram carcaças com maior camada de gordura subcutânea e menor área de Longissimus dorsi e que o grau de marmorização da carne não foi afetado significativamente pelas diferentes fontes protéicas .

\section{4 - Conclusões}

Para machos não castrados em terminação, o presente estudo indica que, ao contrariando o NRC (1996) níveis I, animais alimentados com dietas contendo ao redor de $70 \%$ de concentrado, a inclusão de farelo de soja em substituição parcial a uréia resulta em maior GPD sem afetar o CMS. Aparentemente o NRC (1996) superestima o fluxo de proteína metabolizável nas dietas contendo apenas uréia como suplemento protéico. 


\section{CONCLUSÃo}

Para machos não castrados em crescimento, o presente estudo esta de acordo com NRC (1996) níveis I que indicam a necessidade de inclusão de farelo de soja ou outra fonte suplementar de proteína verdadeira na dieta, em substituição parcial ou total a uréia, com o objetivo de suprir as exigências em proteína metabolizável.

Para machos não castrados em terminação, o presente estudo indica que, ao contrariando o NRC (1996) níveis I, animais alimentados com dietas contendo ao redor de $70 \%$ de concentrado, a inclusão de farelo de soja em substituição parcial a uréia resulta em maior GPD sem afetar o CMS. Aparentemente o NRC (1996) superestima o fluxo de proteína metabolizável nas dietas contendo apenas uréia como suplemento protéico. 


\section{REFERÊNCIAS BIBLIOGRÁFICAS}

ALIO, A.; THEURER, C. B.; LOZANO, O.; HUBER, J.T. ; SWINGLE, R.S.; DELGADO-ElORDUY, A; CUNEO, P.; DeYOUNG, D. e Webb, Jr., K.E., Splanchinic nitrogen metalolism by growing beef steers fed diets containing sorghum grain flaked at different densities. Journal Animal Science. v:78, p. $1355-1363.2000$.

ASSOCIATION OF OFFICIAL ANALYTICAL CHEMISTS. Official Methods of Analysis. 15.ed. Arlington: AOAC, 1990. v.1, 1117p.

BARTLE S.J.; PERSTON, R.L.; MILLER, M.F.; Dietary energy-source and density effects of roughage source, roughage equivalent, tallow level, and steer type on feedlot performance and carcass characteristics. Journal of Animal Science, v. 72, p.1953-1960, 1994.

BUNTING, L.D.; BOLING, J.A.; MACKOWN, C.T.; MUNTIFERING, R.B. Effect of dietary protein level on $\mathrm{N}$ metabolism in lambs: Studies using ${ }^{15} \mathrm{~N}$. Journal of Animal Science, v.64, p.855-867, 1987.

CHALUPA, W. Problems in feed urea to ruminants. Journal of Animal Science, v.27, p.207-219, 1968. 
COOPER, R.J.; MILTON, C.T.; KLOPFENSTEIN, T.J.; JORDON, D.J. Effect of corn processing on degradable intake protein requirement of finishing cattle. Journal of Animal Science, v.80, p.242-247, 2002.

DEVANT, M.; FERRET, A.; CALSAMIGLIA, S.; CASALS, R.; GASA, J. Effect of nitrogen source in high-concentrate, low, protein beef cattle diets on microbial fermentation studied in vivo and in vitro. Journal of Animal Science, v.79, p.1944-1953, 2001.

DEVANT, M.; FERRET, A.; GASA, J.; CALSAMIGLIA, S.; RASALS, R. Effects of protein concentration and degradability on performance, ruminal fermentation, and nitrogen metabolism in rapidly growing heifers fed highconcentrate diets from 100 to $230 \mathrm{~kg}$ body weight. Journal of Animal Science, v.78, p.1667-1676, 2000.

EUCLIDES FILHO, K.; EUCLIDES, V.P.B.; FIGUEIREDO, G.R. et al. Efeito da suplementação com concentrado sobre características de carcaça de bovinos Nelore. In: REUNIÃO ANUAL DA SOCIEDADE BRASILEIRA DE ZOOTECNIA, 34., Juiz de Fora. Anais,1997. Juiz de Fora: Sociedade Brasileira de Zootecnia, 1997a. p.326-327.

FERRELL, C.L.; FREETLY, H.C.; GOETSCH, A.L.; KREIKEMEIER, K.K. The effect of dietary nitrogen and protein on feed intake, nutrient digestibility, and nitrogen flux across the portal-drained viscera and liver of sheep consuming high-concentrate diet ad libitum. Journal of Animal Science, v.79, p.13221328, 2001. 
FOX, D.G.; SNIFFEN, C.J.; O'COMMOR, J.D.; RUSSELL, J.B.; VAN SOEST, P.J. A net-carbohydrate and protein system for evaluating cattle diets: III. Cattle requirements and diet adequacy. Journal of Animal Science, v.70, p.3578-3596, 1992.

FOX, D.G.; TYLUTKI, T.P.; VAN AMBURGH, ME.; CHASE, L.E.; PELL, A.N.; OVERTON, T.R.; TEDESCHI, L.O; RASMUSSEN, C.N.; DURBAL, V.M. The net carbohydrate and protein system for evaluating herd nutrition and nutrient excretion. Ithaca NY: Cornell University. 2000. 235p.

FU, C.J.; FELTON, E.E.D.; LEHMKUHLER, J.W.; KERLEY, M.S. Ruminal peptide concentration required to optimize microbial growth and efficiency. Journal of Animal Science, v.79, p.1305-1312, 2001.

GALYEAN, M.L. Protein levels in beef cattle finishing diets: Industry application, university research, and systems results. Journal of Animal Science, v.74, p.2860-2870, 1996.

GOERING, H.K.; VAN SOEST, P.J. Forage fiber analysis (Apparatus, reagents, procedures and some applications). Agricultural Handbook, Washington:D.C.: Agricultural Research Service, 1970. 19p.

HOOVER, W.H.; WEBSTER, T.K.M. Contributions of microbial protein to aminoacid supply. In: CORNELL NUTRITION CONFERENCE. Ithaca, NY, 1996. Proceedings. Ithaca: Cornell University, 1996. p.199-207.

HUNTINGTON, G.B.E.; Hepatic urea synthesis and site and rate of urea removal from blood of beef steers fed alfalfa hay or a high concentrate diets. Canadian Journal of Animal Science, v.69, p.215-223, 1989. 
HUNTINGTON, G.B.E.; ZETINA, E.J.; WHITT, J.M.; POTTS, W. Effects of dietary concentrate level on nutrient absorption, liver metabolism, and urea kinetics of beef steers fed isonitrogenous and isoenergetic diets. Journal of Animal Science, v.74, p.908-916, 1996.

HUNTINGTON, G.B.E.; POORE, M.; HOPKINS, B.; SPEARS, J. Effect of ruminal protein degradability on growth and $\mathrm{N}$ metabolism in growing beef steers. Journal of Animal Science, v.79, p.533-541, 2001.

HUSTON, J.E.; LIPPKE,H.; FORBES, A.; HOLLOWAY, J.W.; MACHEN, R.V. Effects of supplemental feeding interval on adult cows in western Texas. Journal of Animal Science, v.77, p.3057-3067, 1999.

HUSSEIN, H.S.; BERGER, L.L.; Feedlot performance and carcass characteristics of Holstein steers as affected by source of dietary protein and level of ruminally protected lysine and methionine. Journal Animal Science, v. 73, p. $3503-3509,1995$.

ÍTAVO, L.C.V.; SILVA, F.F.; VALADARES FILHO, S.C.; MORAES, E.H.B.K.; PAULINO, P.V.R. Digestibilidade de fenos de gramíneas do gênero cynodon através de indicadores internos. (Compact disc). In: REUNIÃO ANUAL DA SOCIEDADE BRASILEIRA DE ZOOTECNIA, 37., Viçosa, MG, 2000. Anais. Viçosa, MG:SBZ, 2000.

ÍTAVO, L.C.V.; SILVA, F.F.; FERREIRA, C.C.B.; VALADARES FILHO, S.C.; VALADARES, R.F.D.; PAULINO, P.V.R.; MORAES, E.H.B.K.; Indicadores internos para estimativas de produção fecal e digestibilidade de nutrientes em bovinos. (Compact disc). In: REUNIÃO ANUAL DA SOCIEDADE BRASILEIRA DE ZOOTECNIA, 38., Piracicaba, SP, 2001. Anais. Piracicaba, SP:SBZ, 2001. 
ÍTAVO, L.C.V.; VALADARES FILHO, S.C.; SILVA, F.F.; VALADARES, R.F.D.; CECON, P.R.; ÍTAVO, C.C.B.F.; MORAES, E.H.B.K.; PAULINO, P.V.R. Consumo, degradabilidade ruminal e digestibilidade aparente de fenos de gramíneas do gênero cynodon e rações concentradas utilizando indicadores internos. Revista Brasileira de Zootecnia, v.31, n.2, p.1024-1032, 2002.

KLEMESRUD, M.J.; KLOPFENSTEIN, T.J.; LEWIS, A.J. Evaluation of feather meal as a source of sulfur amino acids for growing steers. Journal of Animal Science, v.78, p.207-215, 2000a.

KLEMESRUD, M.J.; KLOPFENSTEIN, T.J.; LEWIS, A.J. Metabolizable metionina and lysine requirements of growing cattle. Journal of Animal Science, v.78, p.199-206, 2000b.

KNAUS, W.F.; BEERMANN, D.H.; GUIROY, P.J.; BOEHM, M.L.; FOX, D.G. Optimization of rate and efficiency of dietary nitrogen utilization through the use of animal by-products and (or) urea and their effects on nutrient digestion in Holstein steers. Journal of Animal Science, v.78, p.1060-1066, 2001.

LOERCH, S.C., BERGER, L.L., PLEGGE, S.D., FAHEY Jr., G.C. Digestibility and rumen escape of soybean meal, blood meal, meat and bone meal and dehydrated alfafa nitrogen. Journal of Animal Science., 57:1037-1047, 1983.

LUCHIARI FILHO, A. Perspectivas da Bovinocultura de Corte no Brasil. In: SIMPÓSIO SOBRE PRODUÇÃO INTENSIVA DE GADO DE CORTE. Campinas, 1988. Anais do Simpósio sobre Produção Intensiva de Gado de Corte. p.1-10. 
MARTHIS, C.P.; COCHRAN, R.C.; HELDT, J.S.; WOODS, C.B.; ABDELGADIR, I.E.O.; OLSON, K.C.; TINGEMEYER, E.C.; VANZANT, E.S. Effects of supplemental degradable intake protein on utilization of medium- to low quality forages. Journal of Animal Science, v.78, p.224-232, 2000.

MILTON, C.T.; BRANDT JUNIOR, R.T.; TITGEMEYER, E.C. Effects of dietary source and concentration in high-grain diets on finishing steer performance and nutrient digestion. Journal of Animal Science, v.75, n.10, p.2813-2823, 1997a.

MILTON, C.T.; BRANDT JUNIOR, R.T.; TITGEMEYER, E.C. Urea in dry-rolled corn diets: finishing steer performance, nutrient digestion, and microbial protein production. Journal of Animal Science, v.75, p.1415-1424, 1997b.

NATIONAL RESEARCH COUNCIL. Nutrient Requirements of Beef Cattle. 6.ed. Washington: National Academy Press, 1984. 90p.

NATIONAL RESEARCH COUNCIL. Ruminant Nitrogen Usage. Washington: National Academy Press, 1985. 138p.

NATIONAL RESEARCH COUNCIL. Nutrient Requirements of Beef Cattle. 7.ed. Washington: National Academy Press, 1996. 242p. 
NOCEK, J.E.; TAMMINGA, S. Site of digestion of starch in the gastrointestinal tract of dairy cows and its effect on milk yield and composition. Journal of Dairy Science, v.74, p.3598-3629, 1991.

OLIVEIRA JUNIOR, R.C. Efeitos de níveis de grão de soja na digestibilidade de nutrientes e no desempenho da lactação de cabras leiteiras. Piracicaba, 1999. 67p. Dissertação (Mestrado) - Escola Superior de Agricultura "Luiz de Queiroz", Universidade de São Paulo.

ØRSKOV, E.R. Nutrición proteica de los rumiantes. Zaragosa: ACRIBIA, 1988. $178 p$.

OWENS, F.N.; GOETSCH, A.L. Ruminal fermentation. In: $\mathrm{CHURCH,} \mathrm{D.C.} \mathrm{(Ed.).}$ The ruminant animal: digestive physiology and nutrition. Englewood Cliffs: Simon \& Schuster, 1988a. cap.8, p.145-171.

OWENS, F.N.; ZINN, R. Protein metabolism of ruminant animal. In: $\mathrm{CHURCH}$, D.C. (Ed.). The ruminant animal: digestive physiology and nutrition. Englewood Cliffs: Simon \& Schuster, 1988b. cap.12, p.227-249.

PERRY, T.W., CECAVA, M.J. Beef Cattle Feeding and Nutrition. 2. ed. Califórnia: Academic Press, San Diego, 1995. 389p.

RUSSEL, J.B.; SNIFFEN, C.J; VAN SOEST, P.J. Effect the carbohydrate and limitation on degradation and utilization of casein by mixed rumen bacteria. Journal of Dairy Science, v.66, p.763-775, 1983. 
RUSSEL, J.B.; O`CONNOR, J.D.; FOX, D.G.; VAN SOEST, P.J.; SNIFFEN, C.J. A net carbohydrate and Protein System for evaluating cattle diets: I. Ruminal fermentation. Journal of Animal Science, v.70, p.3551-3561, 1992.

RUSSEL, J.B. Factors influencing rumen microbial growth and protein yield. In: SOUTHWEST NUTRITION MANAGEMENT CONFERENCE, Arizona, 1994. Proceedings. Arizona: University of Arizona,1994. p.1-6.

SANTOS, F.A.P. Efeito de bicarbonato de sódio, lasalocida e cana-de-açúcar sobre o desempenho de bovinos alimentados com bagaço de cana tratado sob pressão e vapor. Piracicaba, 1991. 127p. Dissertação (Mestrado) Escola Superior de Agricultura "Luiz de Queiroz", Universidade de São Paulo.

SANTOS, F.A.P. Conceitos atuais de nutrição protéica. In: SIMPÓSIO SOBRE PRODUÇÃO ANIMAL, 9., Piracicaba, 1997. Anais. Piracicaba: FEALQ, 1997. p.50-67.

SANTOS, F.A.P. Efeito de fontes protéicas e processamento de grãos no desempenho de vacas leite e digestibilidade dos nutrientes. Piracicaba, 1998. 105p. Tese (Livre Docência) - Escola Superior de Agricultura "Luiz de Queiroz", Universidade de São Paulo.

SAS Institute. SAS/STAT User's guide. Cary: Statistical Analysis System Institute, 1998. 
SCHMIDT, S.P.; JORGENSE, N.A.; BENEVENG, N.J.; BRUNGARD, V.H. Comparison of soybean-meal, formaldehyde treated soybean-meal, urea and starea for steers. Journal of Animal Science, v.37, n.5, p.1233-1237, 1973.

SCHWAB, C.G. Optimizing amino acid nutrition for optimum yields of milk and milk protein. In: SOUTHWEST NUTRITION MANAGEMENT CONFERENCE, Arizona, 1994. Proceedings. Arizona: University of Arizona, 1994. p.114129.

SEIXAS, J.R.C.; EZEQUIEL, J.M.B.; ARAÚJO, W.D.; RESENDE, F.D.; MARTINS JÚNIOR, A.; KRONKA, S.N.; DaSILVA, L.D.F.; DOURADO, J.B.; SOARES, W.V.B. Desempenho de bovinos confinados alimentados com dietas à base de farelo de algodão, uréia ou amiréia. Revista Brasileira de Zootecnia, v.28, n.2, p.432-438, 1999.

SHAIN, D.H.; STOCK, R.A.; KLOPFENSTEIN, T.J.; HEROLD, D.W. Effect of degradable intake protein level on fishing cattle performance and ruminal metabolism. Journal of Animal Science, v.76, p.242-248, 1998.

SILVA F.F.; VALADARES FILHO, S.C.; I TAVO, L.C.V.; VELOSO, C.M.; PAULIN, M.F.; CECON, P.R.; SILVA, P.A.; GALVÃO, R.M. Desempenho produtivo de novilhos nelore, na recria e na engorda, recebendo dietas com diferentes níveis de concentrado e proteína. Revista Brasileira de Zootecnia, v.31, n.1, p. 492-502, 2002 (Suplemento).

SILVA, D.J. Análise de Alimentos: métodos químicos e biológicos. Viçosa, MG: UFV, 1990, 166p. 
SILVA, L.D.F.; EZEQUIEL, J.M.B.; AZEVEDO, P.S.; CATTELAN, J.W.; BARBOSA, J.C.; RESENDE, F.D.; CARMO, F.R.G. Digestão total e parcial de alguns componentes de dietas contendo diferentes níveis de casca de soja e fontes de nitrogênio em bovinos. Revista Brasileira de Zootecnia, v.31, n.3, p.1258-1268, 2002.

SINDT, M.H., STOCK, R.A., KLOPFENSTEIN, T.J., SHAIN, D.H. Effect of protein source and grain type on finishing calf performance and ruminal metabolism. Journal of Animal Science, v.71, p.1047-1056, 1993.

SNIFFEN, C.J.; O'COMMOR, J.D.; VAN SOEST, P.J.; FOX, D.G.; RUSSELL, J.B.; A net-carbohydrate and protein system for evaluating cattle diets: II. Carbohydrate and protein availability. Journal of Animal Science, v.70, p.3562-3577, 1992.

TEDESCHI, L.O. Development and evaluation of models for the Cornell Net Carbohydrate and Protein System: 1. Feed libraries, 2. Ruminal nitrogen and Branched-chain volatile fatty acid deficiencies, 3. Diet optimization, 4. Energy requirement for maintenance and growth. Ithaca, 2001. 414p. Thesis (PhD) - Cornell university.

TEDESCHI, L.O.; FOX, D.G.; RUSSELL, J.B. Accounting for the effects of a ruminal nitrogen deficiency within the structure of the Cornell Net Carbohydrate and Protein System. Journal of Animal Science, v.78, p.1648-1658, 2000. 
TEDESCHI, L.O.; BOIN, C.; FOX, D.G.; LEME, P.R.; ALLEONI, G.F.; LANNA, D.P.D. Energy requirement for maintenance and growth of Nellore bulls and steers fed high-forage diets. Journal of Animal Science, v.80, p.1671-1682, 2002.

TEIXEIRA, J.C.; DELGADO, E.F; CORREA, E.M.; MORON, I.R. Cinética da digestão ruminal da amiréia 45-S em vacas da raça holandesa. Ciência e Agrotecnologia, v.23, n.3, p.719-723, 1999.

THEURER, C.B.; HUNTINGTON, G.B.; HUBER, J.T.; SWINGLE, R.S.; MOORE, J.A. Net absorption and utilization of nitrogenous compounds across ruminal, intestinal, and hepatic tissues of growing beef steers fed dryrolled or steam-flaked sorghum grain. Journal of Animal Science, v.80, p.525-532, 2002.

THOMPSON, L.H.; WISE, M.B.; BARRICK, E.R.; HARVEY, R.W. Starea, urea and sulfur in beef-cattle rations. Journal of Animal Science, v.35, n.2, p.474-480, 1972.

TITGEMEYER, E.C.; GRIEGER, D.M.; OLSON, K.C.; STOKKA. G. Effect of increasing proportion of supplemental $\mathrm{N}$ from urea in prepartum supplements on range beef cows performance and on intake and digestibility by steers $\mathrm{fd}$ low-quality forage. Journal of Animal Science, v.80, p.1652-1662, 2002. 
VALADARES FILHO, S.C. Eficiência de síntese de proteína microbiana, degradação ruminal e digestibilidade intestinal da proteína bruta, em bovinos. In: SIMPÓSIO INTERNACIONAL SOBRE EXIGÊNCIAS NUTRICIONAIS DE RUMINANTES. Viçosa, UFV, 1995. Anais do Simpósio Internacional sobre Exigências Nutricionais de Ruminantes. p.355-388.

VAN SOEST, P.J. Nutrition ecology of the ruminant. 2.ed. Ithaca: Cornell University Press, 1994. 476p.

VAN SOEST, P.J.; ROBERTSON, J.B.; LEWIS, B.A. Methods for dietary fiber, neutral detergent fiber, and nonstarch polysaccharides in relation to animal nutrition. Journal of Dairy Science, v.74, p.3583-3597, 1991.

VAZ, F.N. Cruzamento alternado das raças Charolês e Nelore: características de carcaça e da carne de novilhos abatidos aos dois anos. Santa Maria, 1999. 58p. Dissertação (Mestrado) - Universidade Federal de Santa Maria.

WHITTENBURRY, R.; McDONALD, P.; BRYAN JONES, D.G. A short review of some biochemical and microbiological aspects of ensilage. Journal of Science of Food and Agriculture, v.18, n.2, p.441-444, 1967.

WILSON, B.B.; WOODS, W. Effect of level of gelatinized corn upon animal performance and rumen fermentation. Journal of Animal Science, v.25, p.912-912, 1966.

WILSON, B.B.; WOODS, W. Effect of increasing levels of gelatinized corn upon rumen metabolism. Journal of Animal Science, v.26, p.932-932, 1967. 
ZINN, R.A. Reevaluation of urea in feedlot diets. In: SOUTHWEST NUTRITION MANAGEMENT CONFERENCE, Arizona, 1994. Proceedings. Arizona: University of Arizona, 1994. p.17-28.

ZINN, R.A.; OWENS, F. N.; Site of protein digestion in steers: Predictability. Journal of Animal Science. v.56, p. 707-716. 1983.

ZINN, R.A.; OWENS, F.N. Ruminal escape protein for lightweight feedlot calves. Journal of Animal Science, v.71, p.1677-1687, 1993.

ZINN, R.A.; SHEN, Y. An evaluation of ruminally degradable intake protein and metabolizable amino acid requirements of feedlot calves. Journal of Animal Science, v.76, p.1280-1289, 1998.

ZINN, R.A.; BARRAJAS, R. ; MONTANO, M.; WARE, R.A.; Influence of dietary urea level on digestive function ande growth performance of cattle fed steamflaked barley finishing diets. Journal of Animal Science, v.81, 2383-2389, 2003. 